\title{
Till geochemical signatures associated with the Sisson W-Mo deposit, New Brunswick, Canada
}

\author{
M. B. McClenaghan ${ }^{1 *}$, A.A. Seaman ${ }^{2}$, M. A. Parkhill ${ }^{3}$, and A.G. Pronk ${ }^{2}$ \\ 1. Geological Survey of Canada, 601 Booth Street, Ottawa, Ontario K1A 0E8, Canada \\ 2. New Brunswick Department of Energy and Mines, Geological Surveys Branch, Fredericton, New Brunswick E3B 5H1, Canada \\ 3. New Brunswick Department of Energy and Mines, Geological Surveys Branch, Bathurst, New Brunswick E2A 3Z1, Canada \\ ${ }^{\star}$ Corresponding author $<$ bmcclena@nrcan.gc.ca $>$
}

Date received: 21 February 2014 Date accepted: 01 July 2014

\begin{abstract}
A till composition study was carried out around the Sisson W-Mo deposit, New Brunswick, Canada, one of the largest $\mathrm{W}$ deposits in the world, to test modern analytical methods for $\mathrm{W}$ in till and document glacial dispersal from a significant $\mathrm{W}$ source. The $<0.063 \mathrm{~mm}$ fraction of till defines glacial dispersal down ice of the deposit and use of this fraction is recommended for W-Mo exploration in the region. Metal-rich till overlying the deposit contains up to $816 \mathrm{ppm} \mathrm{W}$ and $63 \mathrm{ppm}$ Mo. One km down ice, till contains $75 \mathrm{ppm} \mathrm{W}$ and $8 \mathrm{ppm} \mathrm{Mo}$, and till in background areas contains a maximum of $7 \mathrm{ppm} \mathrm{W}$, and $2 \mathrm{ppm}$ Mo. Indicator elements for the deposit include W and Mo, and pathfinder elements include Ag, As, $\mathrm{Bi}, \mathrm{Cd}, \mathrm{Cu}, \mathrm{In}, \mathrm{Pb}, \mathrm{Te}$, and $\mathrm{Zn}$. This list of elements is more extensive than previously identified for the Sisson deposit or identified in other published till geochemical studies because of the polymetallic nature of the Sisson deposit and the broad suite of elements that can now be determined using modern analytical techniques. Lithium meta/tetraborate fusion inductively coupled plasma-mass spectrometry was used to determine the total concentration of $\mathrm{W}$ in till and is a fast and cost effective method as compared to those reported in the older literature. Glacial dispersal of $\mathrm{W}$ and Mo from the Sisson deposit is detectable at a regional scale at least $14 \mathrm{~km}$ down ice (southeast) using surface till sampling. A $2 \mathrm{~km}$ till sample spacing should be sufficient to detect glacial dispersal from a W-Mo deposit of this size.
\end{abstract}

\section{RÉSUMÉ}

Une étude de composition du till a été réalisée autour du dépôt de Sisson, composé de tungstène et de molybdène et situé au Nouveau-Brunswick, au Canada. Il s'agit de l'un des plus importants dépôts de tungstène au monde. L'étude a été réalisée pour mettre à l'essai les méthodes modernes d'analyse du tungstène contenu dans le till et pour obtenir des données sur la dispersion glaciaire d'une importante source de tungstène. La fraction inférieure à $0,063 \mathrm{~mm}$ du till définit la dispersion glaciaire du dépôt sous la glace et on recommande l'utilisation de cette fraction pour l'exploration du tungstène-molybdène dans la région. Le till riche en métal sus-jacent au dépôt contient jusquà $816 \mathrm{ppm}$ de tungstène et $63 \mathrm{ppm}$ de molybdène. À un kilomètre sous la glace, le till contient $75 \mathrm{ppm}$ de tungstène et $8 \mathrm{ppm}$ de molybdène, tandis que la partie inférieure du till contient tout au plus $7 \mathrm{ppm}$ de tungstène et $2 \mathrm{ppm}$ de molybdène. Parmi les éléments indicateurs du dépôt, on trouve du tungstène et du molybdène, et les indicateurs géochimiques comprennent notamment l'argent, l'arsenic, le bismuth, le cadmium, le cuivre, l'indium, le plomb, le tellure et le zinc. Puisque le dépôt de Sisson est de nature polymétallique et qu'il est maintenant possible de définir une vaste gamme déléments grâce aux techniques modernes d'analyse, la liste déléments est plus longue que celle précédemment établie pour le dépôt de Sisson ou que ce qui a été publié dans d’autres études géochimiques du till. Pour déterminer la concentration totale de tungstène dans le till, on a eu recours à la spectrométrie de masse avec plasma à couplage inductif avec fusion au méta/tétraborate de lithium, qui constitue une méthode plus rapide et économique que celles signalées dans la documentation précédente. Il est possible de détecter la dispersion glaciaire du tungstène et du molybdène du dépôt de Sisson à léchelle régionale à au moins $14 \mathrm{~km}$ sous la glace (sud-est) au moyen de léchantillonnage de surface du till. Un intervalle de prélèvement du till de $2 \mathrm{~km}$ devrait suffire pour détecter la dispersion glaciaire d'un dépôt de tungstènemolybdène de cette taille.

[Traduit par la redaction] 


\section{INTRODUCTION}

Tungsten is a dense hard metal with a high melting point and resistance to corrosion that make it optimal for a wide range of applications including hard metals, high density applications, lighting, electronics, and tungsten chemical compounds (Stewart et al. 2011). China produces most of the $\mathrm{W}$ that is consumed globally and now restricts its $\mathrm{W}$ exports to meet its own domestic demands. As a result, there is an increasing need for exploration and development of new W resources elsewhere in the world (United States Geological Survey 2014).

The use of till geochemistry for $\mathrm{W}$ exploration in glaciated terrain is well documented (e.g., Brundin and Bergstrom 1977; Toverud 1984; Salminen and Hartikainen 1986; Snow and Coker 1987; Coker et al. 1988; Rogers et al. 1990); however, most published reports date back to till sampling surveys or programs carried out the 1970s and 1980s. Analytical methods for W have improved significantly since that time and consequently, the determination of the $\mathrm{W}$ content in till is now routine and inexpensive, and many more elements on the periodic table may now also be determined. In the past 20 years, however, no case studies have been published that describe till geochemical signatures around $\mathrm{W}$ mineralization using these modern analytical methods. The Sisson W-Mo deposit in eastern Canada provides an ideal site to test the ability of modern analytical methods to determine $\mathrm{W}$ content in till as well as identify pathfinder elements using the broad range of elements that can now be determined, document the multi-element geochemical signature of a significant W-Mo deposit at varying distances down ice, and develop specific recommendations to improve the application of till geochemistry to W-Mo exploration in glaciated terrain.

The deposit was chosen as a test site because: (1) mineralized rocks subcrop below till and were exposed to glacial erosion; (2) it is till covered and thus material is available for sampling; and (3) it has a previously identified till geochemical dispersal train down ice and thus, metal-rich till is available for targeted sampling. The study described here was carried out as part of the Geological Survey of Canada's (GSC) Targeted Geoscience Initiative 4 (TGI-4), a collaborative federal geoscience program with a mandate to provide industry with the next generation of geoscience knowledge and innovative techniques that will result in more effective targeting of buried mineral deposits. The study was a collaborative effort between the GSC, the New Brunswick Department of Energy and Mines (NBDEM), Northcliff Resources Ltd., and Hunter Dickinson Inc.

\section{Location and Access}

The Sisson W-Mo deposit is in the west-central part of the province of New Brunswick (Fig. 1) in eastern Canada, at latitude $46^{\circ} 22^{\prime} 10^{\prime \prime} \mathrm{N}$ and longitude $67^{\circ} 03^{\prime} 00^{\prime \prime} \mathrm{W}$ in the Coldstream NTS map area (NTS $21 \mathrm{~J} / 06$ ). It is located 60 $\mathrm{km}$ northwest of Fredericton and is easily accessed by truck along logging roads.

\section{GEOLOGY}

\section{Local Bedrock Geology}

The Sisson deposit is a bulk tonnage W-Mo intrusionrelated deposit that has been explored by various companies over the past 50 years. The geology of the deposit area is summarized below from Nast and Williams-Jones (1991), Marr (2009), Fyffe et al. (2008, 2010), and Rennie et al. (2013). The deposit occurs at the eastern contact of the Nashwaak Granite and Howard Peak Granodiorite plutons (Fig. 2). The Howard Peak Granodiorite grades eastward into and becomes intermixed with gabbro. Both the gabbro and granodiorite are transected by granite dykes that are likely offshoots of the Nashwaak pluton. All of these plutons are part of a group of Late Silurian to Early Devonian plutonic rocks that form a northeast-trending belt underlying the Miramichi Highlands in central New Brunswick. The intrusive belt also hosts the Lake George Sb deposit 60 $\mathrm{km}$ south of the Sisson deposit, the Burnthill W, Sn, and Mo showings $30 \mathrm{~km}$ to the northeast, and the Mount Pleasant deposit $100 \mathrm{~km}$ to the south (Fig. 1).

East of the Howard Peak Granodiorite are Ordovician tuffaceous volcanic and sedimentary rocks of the Turnbull Mountain Formation (Fig. 2) of the Tetagouche Group, a belt of strongly deformed Ordovician rocks that extends from the Bathurst area to the northeast, through the Sisson area, and into the southwestern corner of New Brunswick. East of these Turnbull Mountain Formation rocks are quartzite and shale of the Cambrian-Ordovician Miramichi Group (Knights Brook Formation). This package is overlain to the east by additional Tetagouche Group rocks including pyritiferous black shale intercalated with felsic volcanic rocks and mafic volcanic rocks of the Hayden Lake Formation as well as wacke and shale of the Push and Be Damned Formation (Fig. 2).

The Ordovician volcanic and sedimentary rocks (Tetagouche Group), which underlie the east part of the Sisson area, are a continuation of the belt of rocks that host volcanogenic massive sulphide (VMS) deposits of the Bathurst Mining Camp in northeastern New Brunswick. For this reason, the Sisson area was the focus of major exploration programs from the 1950s into the 1990s. These activities led to the discovery in 1960 of the small but high-grade Nash- 


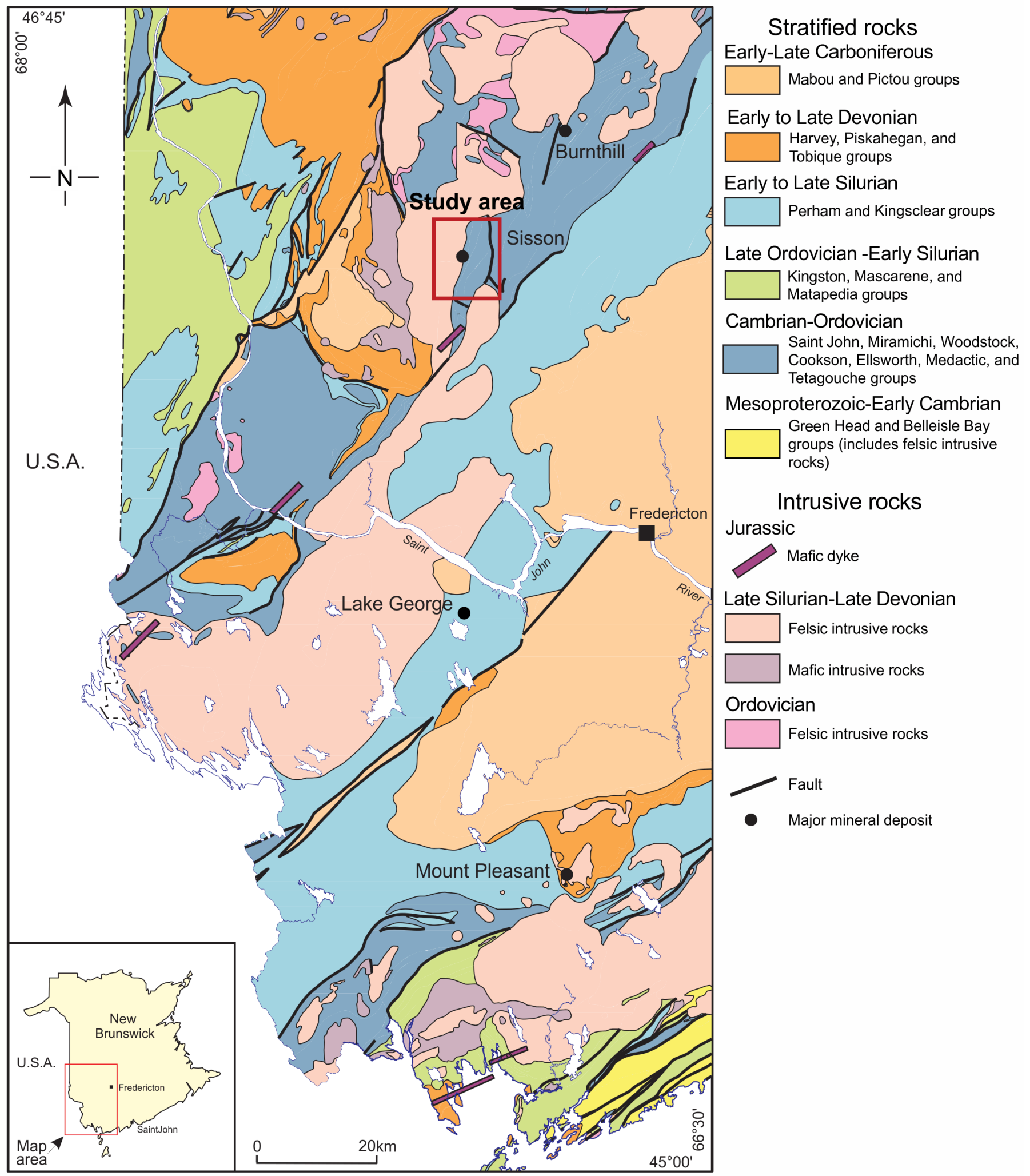

Figure 1. Bedrock geology of west-central and southern New Brunswick showing the location of the Sisson W-Mo deposit and other significant deposits (modified from Fyffe et al. 2010). 


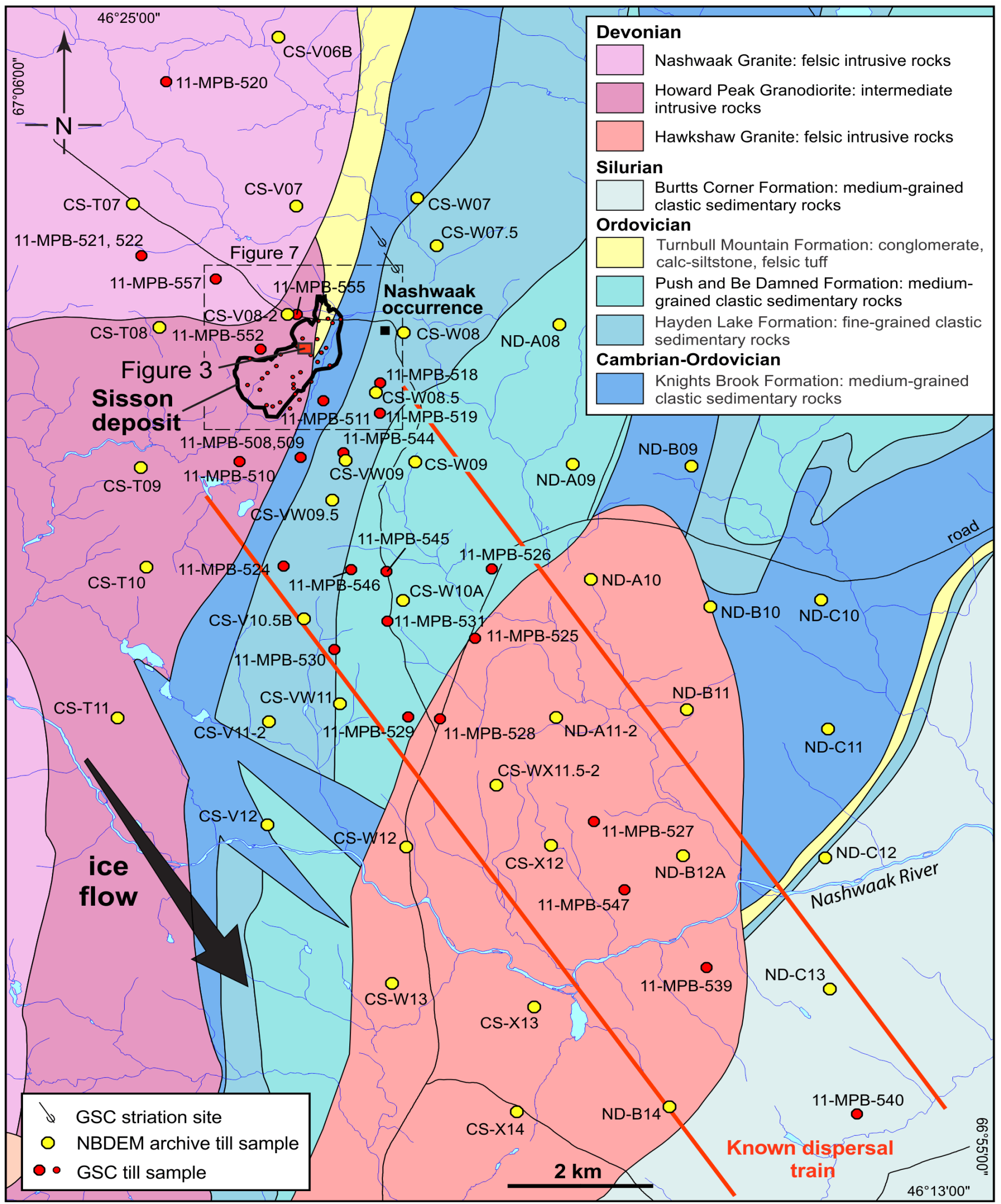

Figure 2. Local bedrock geology of the Sisson W-Mo deposit area, approximate location of glacial dispersal train (red lines) identified by Seaman and McCoy (2008), and location of GSC till samples (red dots) collected in 2011 up ice (northwest), overlying (smaller red dots), and down ice (southeast) of the deposit. Archived New Brunswick Department of Energy and Mines till samples re-analyzed in this study are shown as yellow dots. Bedrock geology modified from Smith and Fyffe (2006a-d). Black deposit outline from Rennie et al. (2013). 
waak $\mathrm{Pb}-\mathrm{Zn}$-Ag-Sb occurrence (Fig. 2) subcropping under thin till cover, only $\sim 900 \mathrm{~m}$ east of the Sisson deposit. This occurrence is a stratabound pod and was originally interpreted as a syngenetic VMS showing (e.g., Snow and Coker 1987). More recently, the $\mathrm{Pb}-\mathrm{Zn}-\mathrm{Ag}-\mathrm{Sb}$ mineralization has been interpreted to be a vein-type showing related to the Sisson mineralizing system (Marr 2009; Rennie et al. 2013; New Brunswick Department of Energy and Mines 2013).

\section{Deposit Geology}

The Sisson deposit is a large, structurally controlled, intrusion-related W-Mo deposit consisting of four wide and steeply dipping zones of vein- and fracture-controlled W and Mo mineralization that straddle the strongly sheared contact of the Howard Peak Granodiorite (Fig. 2). The geology of the local area and deposit are summarized below from Nast and Williams-Jones (1991), Marr (2009), and Rennie et al. (2013). Zone III (scheelite/molybdenite) and the adjacent Zones I and II (chalcopyrite, wolframite) of the Sisson deposit were discovered by Texasgulf Sulphur/Kidd Creek Mines Ltd. between 1978 and 1982 through geophysical surveys, trenching, soil sampling, and drilling (Snow and Coker 1987; Marr 2009; Rennie et al. 2013). The property was further explored by various operators between 1997 and 2004. In 2007, a large exploration trench was excavated to expose the bedrock surface of Zone III (Fig. 3) and in 2008 the Ellipse Zone was discovered (Fig. 4).

Mineralization is likely related to the presence of a buried granitic stock at depth, which was the heat source for a hydrothermal system and metals. Zones I, II, and III strike roughly north-south and the Ellipse Zone strikes northwest-southeast (Fig. 4). The zones merge at depth and are part of a much larger hydrothermal mineralizing system with an area of at least $9 \mathrm{~km}^{2}$. Mineralization in all four zones subcrops at the till-bedrock interface and is open at depth. Zone III and the Ellipse Zone are the largest and best explored parts of the deposit and contain molybdenite

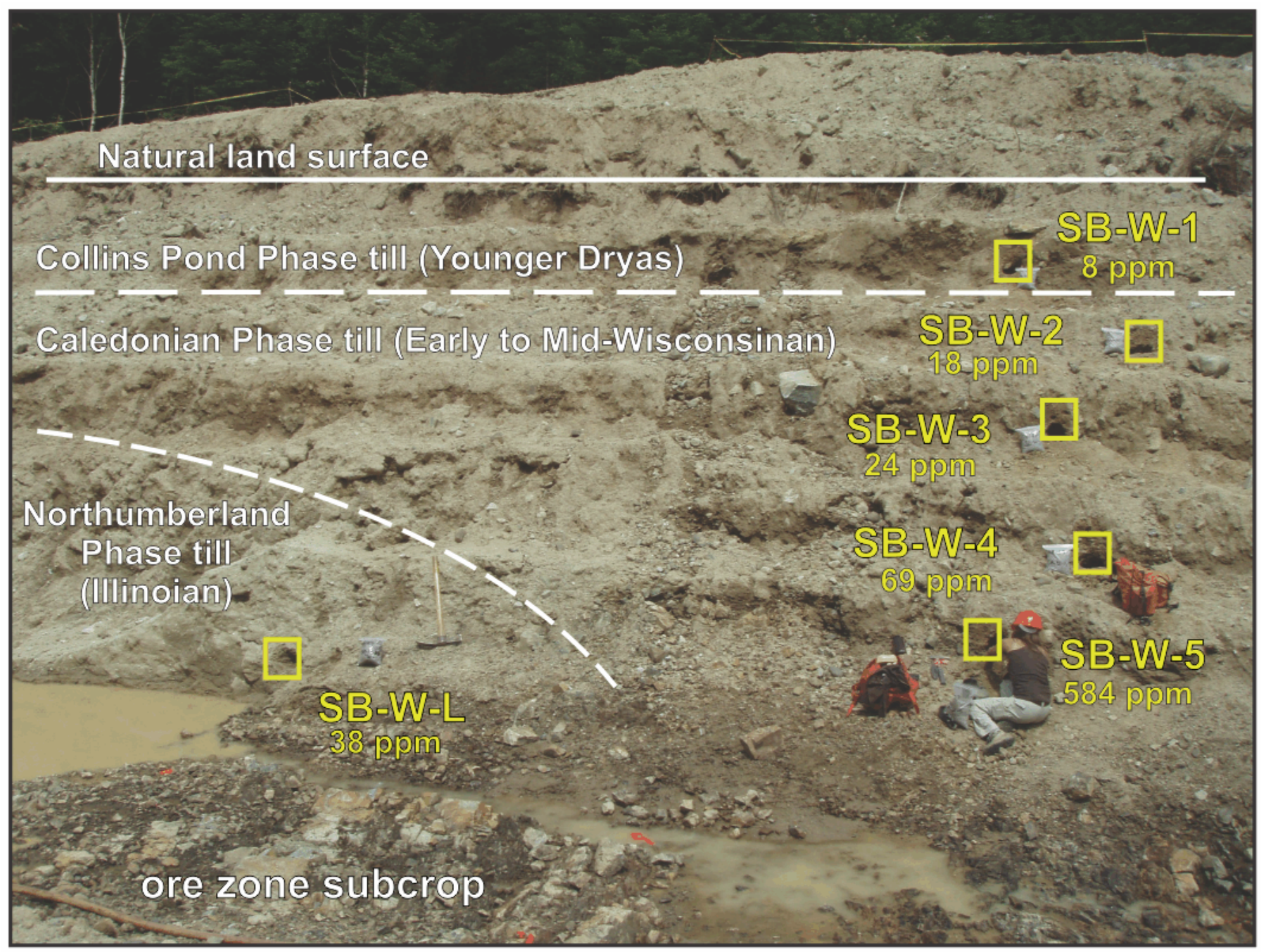

Figure 3. Photograph of thick $(6 \mathrm{~m})$ till section exposed in the western part of the Geodex Minerals Ltd. large exploration trench in 2007, showing the $\mathrm{W}$ content, determined by instrumental neutron activation analysis, in the $<0.063 \mathrm{~mm}$ fraction of New Brunswick Department of Energy and Mines till samples (SB-W-1 to -5, SB-W-L) (modified from Seaman and McCoy 2008). 


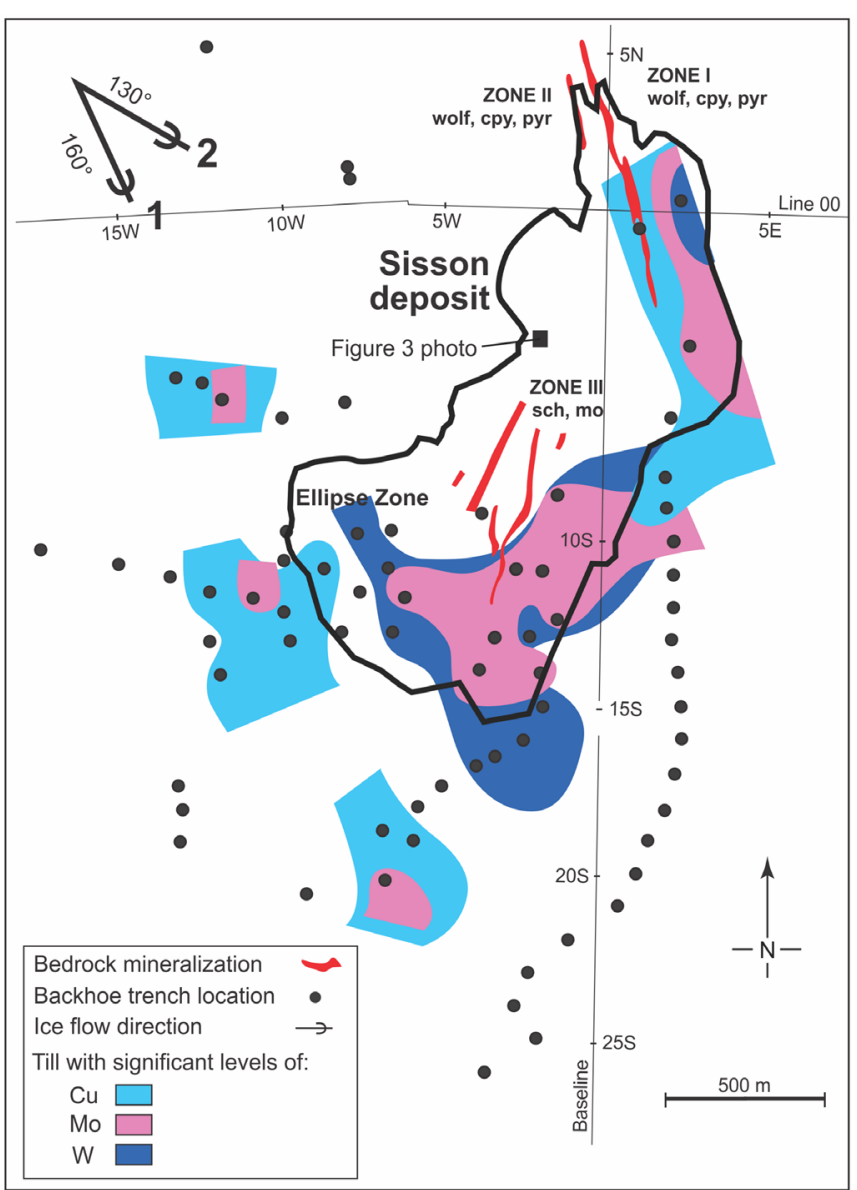

Figure 4. Till sample locations and distribution of $\mathrm{W}$ (fusion/colourimetry), $\mathrm{Mo}$, and $\mathrm{Cu}$ (aqua regia/AAS) in the $<2.0 \mathrm{~mm}$ fraction of till reported in Snow and Coker (1987). Ice-flow chronology: $1\left(160^{\circ}\right)$ is the older ice-flow phase, and $2\left(130^{\circ}\right)$ is the younger ice-flow phase.

Location of mineralized zones identified in the1980s indicated by red polygons. Sisson deposit outline shown as a thick black line and names of mineralized zones are from Rennie et al. (2013).

and scheelite in sheeted quartz veins and stockworks. The deposit has elevated concentrations of $\mathrm{Cu}, \mathrm{Zn}, \mathrm{Pb}, \mathrm{Bi}$, and As that are directly related to late quartz-scheelite and sulphide-rich veins and their sericite-sulphide envelopes. Rennie et al. (2013) reported resource estimates for the deposit of $383 \mathrm{Mt}$ at $0.069 \% \mathrm{WO}_{3}$ and $0.023 \% \mathrm{Mo}$ (proven) and 178 Mt at $0.065 \mathrm{WO}_{3}$ and $0.020 \% \mathrm{Mo}$ (probable), making it one of the largest tungsten deposits in the world. Ore minerals in the deposit consist of scheelite, minor wolframite, and molybdenite. Other sulphide, oxide and telluride minerals present are listed in Table 1.

\section{Surficial Geology}

Bedrock outcrops on the Sisson property and in the surrounding area are rare due to the locally thick and continuous cover of till. Till thickness varies from $<2 \mathrm{~m}$ to $20 \mathrm{~m}$ over the deposit, and is on average $\sim 8 \mathrm{~m}$ thick over Zone III (Marr 2009). The deposit area is overlain by one to three till units which have been described in detail by Seaman and McCoy (2008) and Fyffe et al. (2010), largely from a section exposed in the large exploration trench (Fig.3, location shown in Fig. 4). The stratigraphic interpretation of the tills overlying the deposit was subsequently revised by Seaman (2009), Seaman et al. (2011), and Stea et al. (2011). The lowermost and oldest till is exposed at the base of a section in the western end of the large exploration trench excavated in 2007. It is an Illinoian clay-rich (25\% clay in matrix) basal lodgement till (Fig. 3) deposited during the Northumberland Phase by an east-southeast-flowing ice sheet. Elsewhere in the trench, the bedrock surface and/or the oldest till are overlain by a younger sandier Early Wisconsinan lodgement till (Fig. 3) likely deposited by southeast glacial flow during the Caledonia Phase, and possibly reworked by south-southwest glacial flow during the Middle to Late Wisconsinan (Escuminac Phase). This Early Wisconsinan till is blanketed discontinuously by 0.2 to $2.5 \mathrm{~m}$ of Younger Dryas (Collins Pond Phase) till (Fig. 3), formed during a brief cold period at the very end of the Late Wisconsinan that saw the reactivation or regrowth of glaciers. This Younger Dryas till was deposited discontinuously over the area by westward-flowing ice and has a loose, sandy matrix (57-80\% sand) that is texturally similar to the underlying Caledonia Phase (Early Wisconsinan) lodgement till. This Younger Dryas till formed, in part, by reworking of Late Wisconsinan glaciofluvial and glaciolacustrine sediments including datable organic material (Seaman and McCoy 2008).

\section{Previous Till Geochemical Surveys in the Sisson Area}

In 1982-1983, a till geochemical study of the Sisson deposit area was carried out by Kidd Creek Mines Ltd. Snow and Coker (1987) determined that ice flowing southeast and east-southeast crossed the deposit area. They sampled surface till overlying and up to $8 \mathrm{~km}$ down ice (southeast) of the deposit and identified W, Mo, Cu, As, and F as the key pathfinder elements (Fig. 4) in the heavy mineral (specific gravity $=3.3$ ) and $<2.0 \mathrm{~mm}$ whole till fractions. The highest contents for $\mathrm{W}, \mathrm{Mo}$, and $\mathrm{Cu}$ were reported to be 1400,2020 , and $260 \mathrm{ppm}$, respectively, for the $<2.0 \mathrm{~mm}$ whole till fraction. The areas they identified as metal-rich till correspond to the area overlying and immediately down ice (southeast) of what is now defined as the Sisson deposit by Rennie et al. (2013) (Fig. 4).

As part of a regional till geochemical survey of central New Brunswick, Lamothe (1992) collected till samples in the vicinity of the Sisson and Burnt Hill W deposits. He reported a $10 \mathrm{~km}$-long glacial dispersal train trending southeast from the Sisson deposit in the $<0.002 \mathrm{~mm}$ fraction of till that was best defined by $\mathrm{W}$, but also by $\mathrm{Cu}, \mathrm{Pb}, \mathrm{Zn}$, and $\mathrm{Mo}$.

More recently, surface till (Early Wisconsin sandy till) sampling at one sample per $2 \mathrm{~km}^{2}$ has been carried out 
Table 1. Indicator minerals in the Sisson deposit (Nast and Williams-Jones 1991; Marr 2009) and those found in till heavy mineral concentrates (HMC) from this study (McClenaghan et al .2013a, b). Minerals in HMC pan concentrates were identified visually and confirmed by SEM.

\begin{tabular}{|c|c|c|c|c|c|}
\hline Mineral & Formula & Specific Gravity & Hardness & Presence in bedrock reported by others & Size range in till HMC $(\mathrm{mm})$ \\
\hline $\begin{array}{l}\text { W Minerals } \\
\text { scheelite } \\
\text { wolframite }\end{array}$ & $\begin{array}{c}\mathrm{CaWO}_{4} \\
(\mathrm{Fe}, \mathrm{Mn}) \mathrm{WO}_{4}\end{array}$ & $\begin{array}{c}5.90-6.12 \\
7.1-7.5\end{array}$ & $\begin{array}{l}4-5 \\
4.5\end{array}$ & $\begin{array}{l}\text { Nast and Williams-Jones (1991); Marr (2009) } \\
\text { Nast and Williams-Jones (1991); Marr (2009) }\end{array}$ & $\begin{array}{l}0.025-2.0 \\
0.025-1.0\end{array}$ \\
\hline \multicolumn{6}{|c|}{ Sulphide Minerals } \\
\hline molybdenite & $\mathrm{MoS}_{2}$ & 5.5 & 1.0 & Nast and Williams-Jones (1991); Marr (2009) & $0.075-2.0$ \\
\hline pyrite & $\mathrm{FeS}_{2}$ & $5.00-5.02$ & 6.5 & Nast and Williams-Jones (1991); Marr (2009) & $0.025-0.05$ \\
\hline chalcopyrite & $\mathrm{CuFeS}_{2}$ & $4.1-4.3$ & 3.5 & Nast and Williams-Jones (1991); Marr (2009) & $0.2-2.0$ \\
\hline sphalerite & $(\mathrm{Zn}, \mathrm{Fe}) \mathrm{S}$ & $3.9-4.2$ & $3.5-4.0$ & Nast and Williams-Jones (1991); Marr (2009) & $0.05-2.0$ \\
\hline galena & $\mathrm{PbS}$ & $7.2-7.6$ & 2.5 & Nast and Williams-Jones (1991); Marr (2009) & 0.05 \\
\hline pyrrhotite & $\mathrm{Fe}_{(1-\mathrm{x})} \mathrm{S}(\mathrm{x}=0-0.17)$ & $4.58-4.65$ & $3.5-4.0$ & Nast and Williams-Jones (1991); Marr (2009) & not observed \\
\hline arsenopyrite & FeAsS & 6.1 & 5 & Nast and Williams-Jones (1991); Marr (2009) & $0.05-2.0$ \\
\hline \multicolumn{6}{|l|}{ Bi Minerals } \\
\hline bismuthinite & $\mathrm{Bi}_{2} \mathrm{~S}_{3}$ & $6.8-7.2$ & 2.0 & no & $0.25-1.0$ \\
\hline bismutite & $\mathrm{Bi}_{2}\left(\mathrm{CO}_{3}\right) \mathrm{O}_{2}$ & 7.0 & 4.0 & no & $0.025-2.0$ \\
\hline native bismuth & $\mathrm{Bi}$ & $9.7-9.8$ & $2.0-2.5$ & Nast and Williams-Jones (1991); Marr (2009) & $0.025-1.0$ \\
\hline joseite & $\mathrm{Bi}_{4}(\mathrm{~S}, \mathrm{Te})_{3}$ & 8.1 & 2.0 & no & $0.025-0.5$ \\
\hline \multicolumn{6}{|l|}{ Ag Minerals } \\
\hline hessite & $\mathrm{Ag}_{2} \mathrm{Te}$ & $7.2-7.9$ & $1.5-2.0$ & Nast and Williams-Jones (1991) & not observed \\
\hline acanthite & $\mathrm{Ag}_{2} \mathrm{~S}$ & $7.2-7.4$ & $2.0-2.5$ & Nast and Williams-Jones (1991) & not observed \\
\hline
\end{tabular}

in the region by the NBDEM (Seaman 2001, 2002, 2007) (Fig. 5). In addition, Seaman (2003) and Seaman and McCoy (2008) collected till samples at a more detailed scale in the area immediately surrounding the Sisson deposit and from the large exploration trench excavated to expose the bedrock surface of the deposit in 2007 (Fig. 3). They identified elevated concentrations of $\mathrm{W}, \mathrm{As}, \mathrm{Bi}, \mathrm{Cd}, \mathrm{Cs}, \mathrm{Cu}, \mathrm{In}$, $\mathrm{Mo}, \mathrm{Sn}$, and $\mathrm{Zn}$ in the $<0.063 \mathrm{~mm}$ fraction of till overlying the deposit (i.e., Fig. 3) and in a long glacial dispersal train trending SE (135 $)$ (Fig. 5). For the first few kilometres, the dispersal train trends southward, which was interpreted to be caused by the presence of the $100 \mathrm{~m}$-high south-southwest-trending Nashwaak Ridge (Fig. 5). The glacial dispersal train, best defined by Bi content in till, is 2 to $4 \mathrm{~km}$ wide, and extends at least $43 \mathrm{~km}$ southeast of the Sisson deposit. The train is discontinuous in places due to local reworking during subsequent Late Wisconsinan glacial phases.

\section{METHODS}

\section{Till Sampling}

Because previous NBDEM till surveys had identified a multi-element SE-trending dispersal train from the Sisson deposit, till sampling for this study was focused immediately up ice, overlying, and up to $14 \mathrm{~km}$ down ice (southeast) of the deposit (Fig. 2). A total of 75 till samples were collected using established GSC till sampling protocols (Spirito et al. 2011; McClenaghan et al. 2013a-d). In addition to the new samples collected, 39 archived samples from the previous NBDEM regional till sampling survey (Fig. 2) were re-analyzed with the new samples to provide some regional context for interpreting data for samples proximal to the deposit. The new till sampling involved the collection of surface till samples at key distances down ice for indicator mineral and till geochemical studies. Till sampled in this study is likely Early Wisconsinan lodgement till deposited by southeastward ice flow during the Caledonia Phase (Seaman 2009). The overlying very thin $(\leq 0.2 \mathrm{~m})$ sandy $(60-80 \%$ sand) till, which is present at surface in places and suspected as being Younger Dryas till, was not sampled in this study because of its discontinuous nature, low silt content (i.e., a poor candidate for matrix till geochemistry), westward transport direction, and likely ablation derivation. Till samples were collected at an average depth of $1.5 \mathrm{~m}$ from freshly dug trenches that had been excavated for sump drainage pits for diamond drill holes, and from road cuts, hand-dug holes, and diamond drill core. Till samples were mostly weakly oxidized C-horizon material. Till sample locations, site descriptions, photographs, and sample depth information are reported in McClenaghan et al. (2013a). At each site, a $3 \mathrm{~kg}$ till sample was collected for geochemical analysis of the till matrix, textural determinations, and archiving. A second $200 \mathrm{~g}$ till sample was collected in a small disposable plastic lunch bag and was tested in the field while slightly moist. Measurements were taken through the sample bag using a portable bench top Innov-x $5000 \mathrm{XRF}$ to provide preliminary information on the content of $\mathrm{W}, \mathrm{Sn}, \mathrm{Cu}, \mathrm{Mo}, \mathrm{Bi}$, and $\mathrm{As}$ and to guide till sampling. Three till sites were sampled as duplicates to assess field variability.

\section{Sample Processing and Analysis}

Till samples were prepared at GSC Ottawa to recover the $<0.063 \mathrm{~mm}$ fraction using procedures outlined in Spirito et al. (2011) and McClenaghan et al. (2013b, d). The 


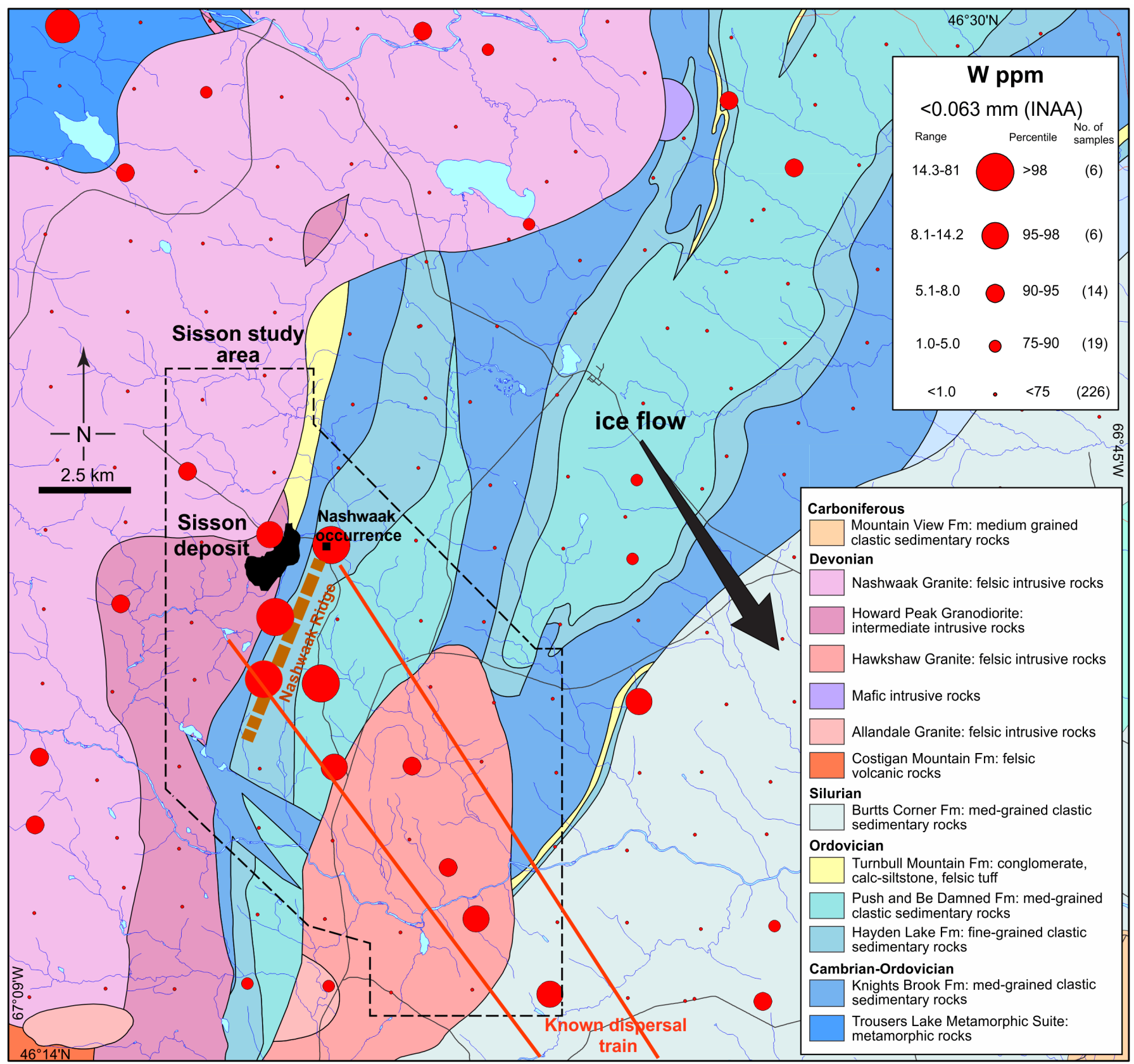

Figure 5. Distribution of $\mathrm{W}$ determined by instrumental neutron activation analysis in the $<0.063 \mathrm{~mm}$ fraction of regional till samples collected by the New Brunswick Department Energy and Mines in the area around the Sisson W-Mo deposit (data from Seaman 2002, 2003, 2007; Seaman and McCoy 2008). The glacial dispersal train from the Sisson deposit identified by Seaman and McCoy (2008) trends southeast for at least $30 \mathrm{~km}$, of which the first $14 \mathrm{~km}$ is shown in this figure.

$<0.063 \mathrm{~mm}$ fraction was chemically analyzed at a commercial laboratory using 1:1 aqua regia/ICP-MS on $0.5 \mathrm{~g}$, and lithium metaborate/tetraborate fusion followed by nitric acid digestion/ICP-ES, -MS on $0.2 \mathrm{~g}$. Because of the lower and variable recovery of $\mathrm{W}$ and $\mathrm{Sn}$ by aqua regia digestion (McClenaghan et al. 2013b), only the total W and Sn values determined by lithium meta/tetraborate fusion/ICPMS are described and plotted here. Three blind duplicates were prepared during sample processing, one from each till field duplicate to monitor analytical precision. CANMET certified reference standards TILL-1, TILL-2, and TILL-4 (Lynch 1996) were inserted into the batch prior to analysis to monitor analytical accuracy. Three silicic acid (silica sand) blanks were sieved at GSC and analyzed as part of the sample batch to monitor cross contamination between metal-rich samples during sample preparation. Geochemical data listings for till samples as well as for blind duplicates, standards, and blanks are reported in McClenaghan et al. (2013b).

The $<0.063 \mathrm{~mm}$ fraction of till was analyzed in this study 
to evaluate if this commonly used size fraction (e.g., Pronk and Burton 1988; Batterson 1989; Lestinen et al. 1991; Koljonen 1992; Friske et al. 2001; McClenaghan et al. 2011) is suitable for $\mathrm{W}$-Mo exploration in the region. To provide the regional context in which to interpret the new till geochemical data for the Sisson area, the archived $<0.063 \mathrm{~mm}$ fraction of 39 till samples (Fig. 2), previously analyzed by NBDEM as part of their regional surveys, were sent to GSC Ottawa. These samples were analyzed as part of the GSC analytical batch in 2011 and data are reported in McClenaghan et al. (2013b).

\section{RESULTS}

Geochemical data for all samples analyzed in this study are reported in McClenaghan et al. (2013b). Appendix A lists a subset of these data that includes only surface till samples within or proximal to the southeast-trending glacial dispersal train defined by Seaman (2003). In this table, data are listed according to location relative to the Sisson deposit: up ice, proximal up ice (within $200 \mathrm{~m}$ of the deposit), overlying, proximal down ice (within $1000 \mathrm{~m}$ of the deposit), and down ice distal (>1000 $\mathrm{m}$ down ice). This table was used to establish the thresholds between background values in till and those in metal-rich till samples overlying and down ice of the deposit. Samples listed above the thick black horizontal line are considered to be background.

\section{Tungsten and tin in the $<0.063 \mathrm{~mm}$ fraction of till}

Background $\mathrm{W}$ contents in till up ice (Appendix $\mathrm{A}$ ) range from 3 to $7 \mathrm{ppm}$. The highest $\mathrm{W}$ values (113 to $816 \mathrm{ppm}$ ) occur in till overlying the Sisson deposit. Slightly elevated values, between 11 and $41 \mathrm{ppm} \mathrm{W}$, occur consistently in till as far as $5 \mathrm{~km}$ down ice (southeast) of the deposit and in one isolated sample $11 \mathrm{~km}$ to the southeast, on the south side of the Nashwaak River (Fig. 6). At the deposit scale, $\mathrm{W}$ content in till is highest: (1) over the north end of the deposit where mineralized bedrock is closest to surface $(<2$ to $4 \mathrm{~m}$ depth) (133 to $290 \mathrm{ppm}$ ), and (2) on the eastern side of the deposit (126 to $816 \mathrm{ppm}$ ) just down ice (southeast) of areas where bedrock is close to surface (Fig. 7). Tungsten values display a strong $(r>0.8)$ positive correlation with $\mathrm{Bi}$ and moderate $(\mathrm{r}=0.6-0.8)$ correlations with $\mathrm{Mo}, \mathrm{Cu}, \mathrm{Zn}$, $\mathrm{Ag}, \mathrm{Cd}, \mathrm{Te}$, and In (Table 2).

Tin contents in till in the Sisson area range from 3 to $28 \mathrm{ppm}$. Background values in till up ice (northwest) range from 4 to 9 ppm Sn (Appendix A). The highest values occur in till overlying and immediately down ice of the deposit. Slightly elevated Sn values of 9 to $21 \mathrm{ppm}$ trend southeast for $6 \mathrm{~km}$ from the deposit, suggesting glacial dispersal in this direction. Tin displays strong $(\mathrm{r}>0.8)$ positive correlations with $\mathrm{Bi}$ and $\mathrm{In}$, and moderate $(\mathrm{r}=0.6-0.8)$ correlations with $\mathrm{W}, \mathrm{Cu}, \mathrm{Pb}, \mathrm{Zn}, \mathrm{Ag}, \mathrm{As}, \mathrm{Cd}$, and Te (Table 2).

\section{Molybdenum, copper, and bismuth in the $<0.063 \mathrm{~mm}$ fraction of till}

Molybdenum values in till in the Sisson area range from 0.4 to $63 \mathrm{ppm}$ (Appendix A). The highest values (10 to 63 $\mathrm{ppm}$ ) occur in till overlying and immediately down ice of the deposit (Fig. 8). Background values up ice range from 0.4 to $1.7 \mathrm{ppm}$ (Appendix A). Slightly elevated values, between 1.7 and $13.3 \mathrm{ppm}$, occur in till $3 \mathrm{~km}$ down ice (southeast) but also were found in till overlying Cambrian-Ordovician and Ordovician metasedimentary rocks of the Tetagouche Group southeast to northeast of the deposit, including in the area of the Nashwaak occurrence. Two elevated values,

Table 2. Correlation matrix of selected log transformed elements determined by aqua regia/ICP-MS or lithium meta/tetraborate fusion/ICP-MS (Sn, W) in the $<0.063 \mathrm{~mm}$ fraction of till samples from the Sisson W-Mo deposit area $(\mathrm{N}=111)$.

\begin{tabular}{|c|c|c|c|c|c|c|c|c|c|c|c|c|c|c|}
\hline Sn-tot & $\begin{array}{r}\text { Sn-tot } \\
1.00\end{array}$ & $\mathrm{~W}$-tot & Mo & $\mathrm{Cu}$ & $\mathrm{Pb}$ & $\mathrm{Zn}$ & $\mathrm{Ag}$ & As & $\mathrm{Cd}$ & $\mathrm{Sb}$ & $\mathrm{Bi}$ & $\mathrm{Se}$ & $\mathrm{Te}$ & In \\
\hline $\mathrm{W}$-tot & 0.74 & 1.00 & & & & & & & & & & & & \\
\hline Mo & 0.54 & 0.78 & 1.00 & & & & & & & & & & & \\
\hline $\mathrm{Cu}$ & 0.77 & 0.79 & 0.67 & 1.00 & 0.71 & & & & & & & & & \\
\hline $\mathrm{Pb}$ & 0.73 & 0.53 & 0.48 & 0.71 & 1.00 & & & & & & & & & \\
\hline $\mathrm{Zn}$ & 0.76 & 0.60 & 0.46 & 0.73 & 0.80 & 1.00 & & & & & & & & \\
\hline $\mathrm{Ag}$ & 0.60 & 0.63 & 0.57 & 0.68 & 0.60 & 0.63 & 1.00 & & & & & & & \\
\hline As & 0.60 & 0.51 & 0.50 & 0.74 & 0.77 & 0.58 & 0.68 & 1.00 & & & & & & \\
\hline $\mathrm{Cd}$ & 0.74 & 0.63 & 0.45 & 0.69 & 0.69 & 0.90 & 0.65 & 0.53 & 1.00 & & & & & \\
\hline $\mathrm{Sb}$ & -0.22 & -0.11 & 0.12 & 0.11 & 0.18 & -0.14 & 0.03 & 0.43 & -0.18 & 1.00 & & & & \\
\hline $\mathrm{Bi}$ & 0.87 & 0.83 & 0.58 & 0.87 & 0.61 & 0.71 & 0.69 & 0.66 & 0.76 & -0.16 & 1.00 & & & \\
\hline $\mathrm{Se}$ & 0.24 & 0.16 & 0.21 & 0.27 & 0.45 & 0.18 & 0.19 & 0.46 & 0.10 & 0.28 & 0.13 & 1.00 & & \\
\hline $\mathrm{Te}$ & 0.67 & 0.75 & 0.68 & 0.85 & 0.57 & 0.62 & 0.59 & 0.62 & 0.58 & 0.13 & 0.77 & 0.13 & 1.00 & \\
\hline In & 0.84 & 0.73 & 0.49 & 0.83 & 0.72 & 0.82 & 0.66 & 0.72 & 0.80 & -0.03 & 0.87 & 0.24 & 0.75 & 1.00 \\
\hline
\end{tabular}

Note: Moderate correlations ( $r>0.6)$ are in bold black and strong correlations $(r>0.8)$ are in bold red. 


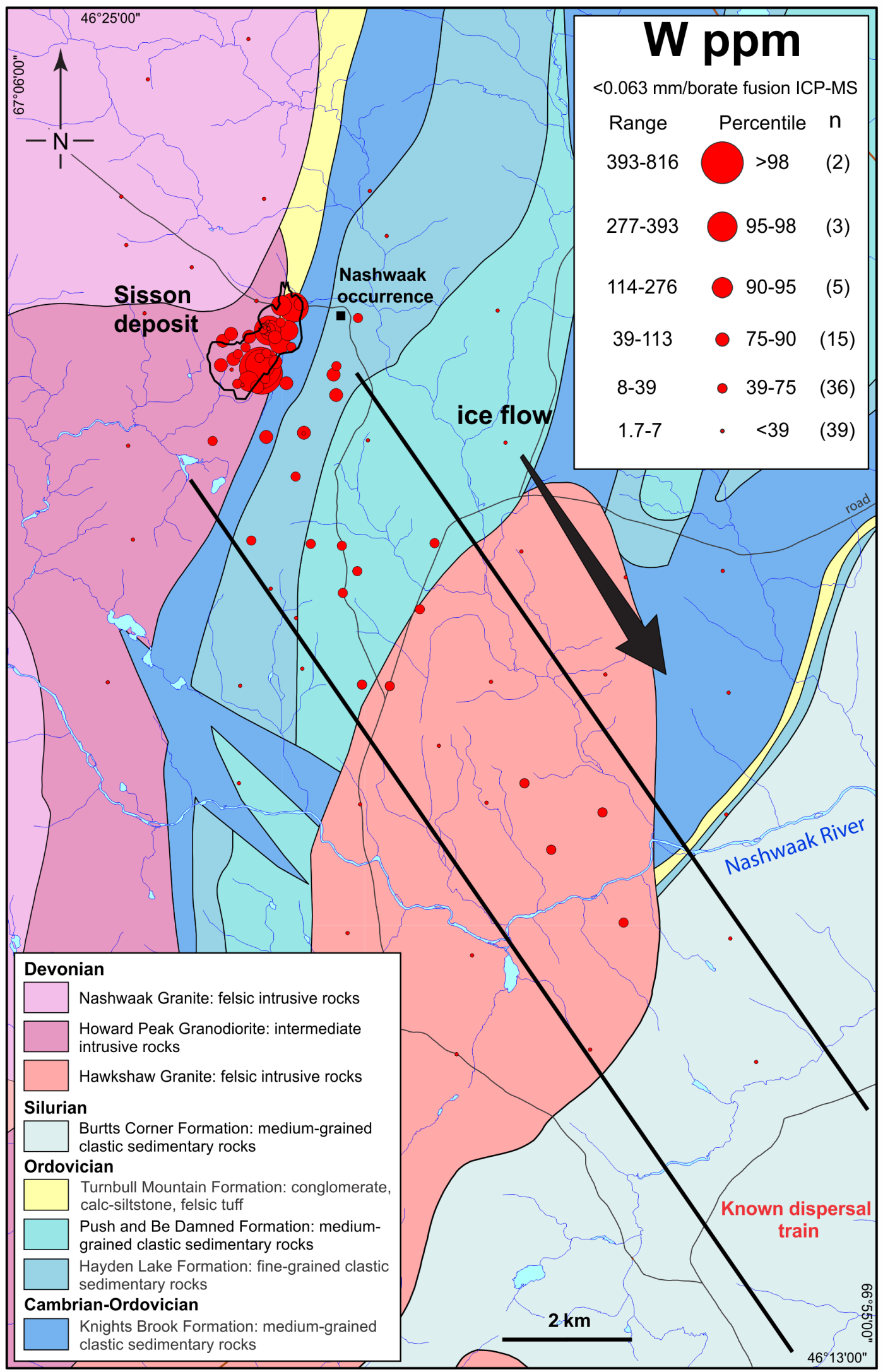

Figure 6. Proportional dot map of W (borate fusion/ICP-MS) abundance in the $<0.063 \mathrm{~mm}$ fraction of surface till samples around the Sisson W-Mo deposit. Bedrock geology modified from Smith and Fyffe (2006a-d). Deposit outline in black is from Rennie et al. (2013) (modified from McClenaghan et al. 2013a). 


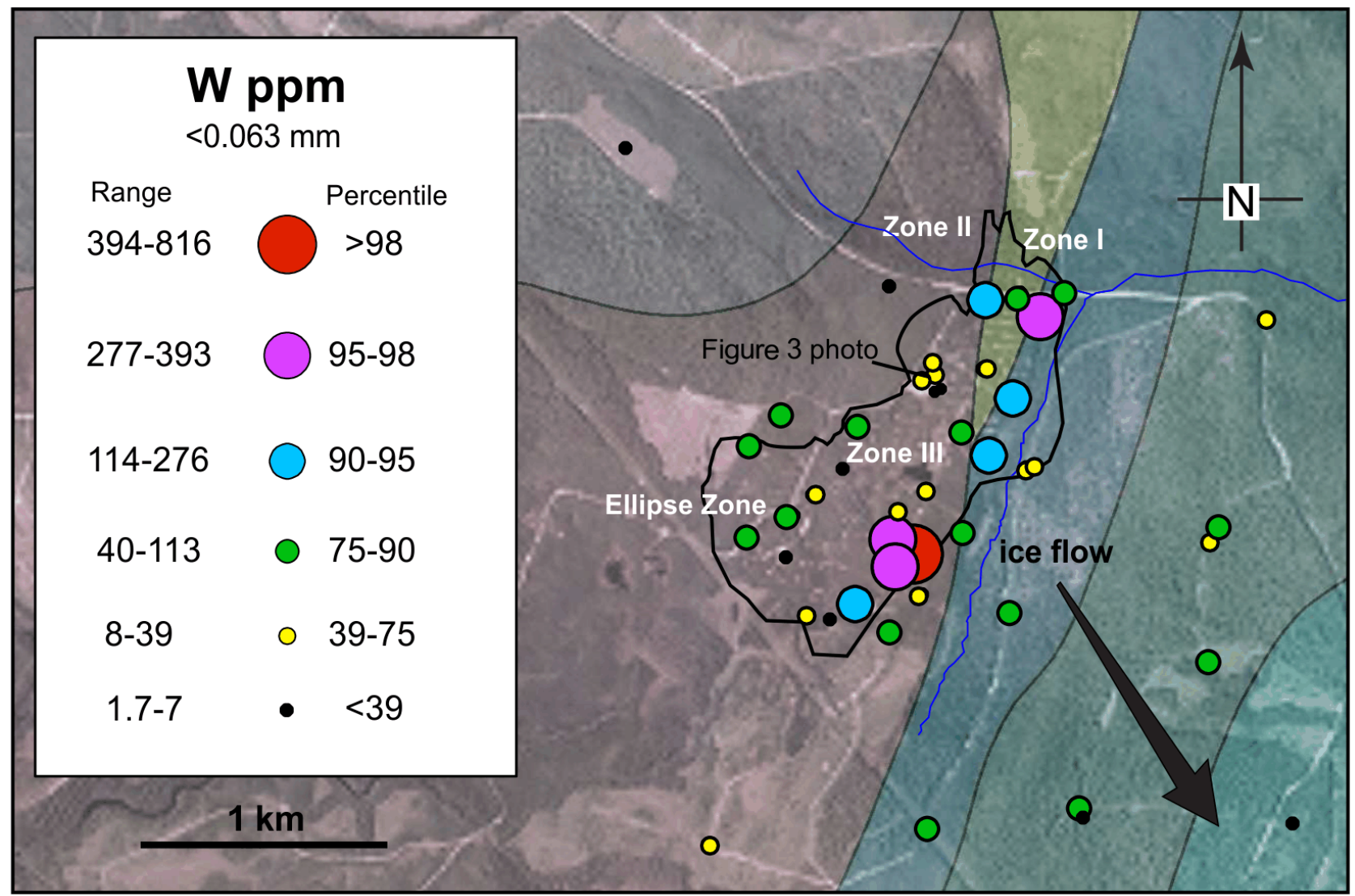

Figure 7. Proportional dot map of $\mathrm{W}$ (borate fusion/ICP-MS) abundance in the $<0.063 \mathrm{~mm}$ fraction of surface till samples overlying and proximal to the Sisson W-Mo deposit. Bedrock units are the same as those shown in Figure 5. Bedrock geology modified from Smith and Fyffe (2006a-d). The aerial photograph in the background provided by Northcliff Resources Ltd. Deposit outline in black is from Rennie et al. (2013) (modified from McClenaghan et al. 2013a).

6.7 and $6.0 \mathrm{ppm} \mathrm{Mo,} \mathrm{occur} \mathrm{in} \mathrm{till} 11$ and $13 \mathrm{~km}$ southeast of the Sisson deposit, on the south side of the Nashwaak River. Molybdenum displays moderate $(\mathrm{r}=0.6-0.8)$ correlations with $\mathrm{W}, \mathrm{Cu}$, and $\mathrm{Te}$ (Table 2).

Copper concentrations in till around the Sisson deposit range between 12 and $978 \mathrm{ppm}$ and background values up ice (northwest) are between 12 and 87 ppm (Appendix A). The highest values in till overlie the deposit (310 to 978 ppm). Slightly elevated values, between 87 and $282 \mathrm{ppm}$, occur in till trending $4 \mathrm{~km}$ southeast from the deposit as well as northeast where it overlies Tetagouche Group rocks. Copper displays strong $(r>0.8)$ positive correlation with $\mathrm{Bi}$, $\mathrm{Te}$, and In, and moderate $(\mathrm{r}=0.6-0.8)$ correlations with $\mathrm{W}$, $\mathrm{Sn}, \mathrm{Mo}, \mathrm{Pb}, \mathrm{Zn}, \mathrm{Ag}$, As, and Cd (Table 2).

Background contents of $\mathrm{Bi}$ in till up ice are between 0.5 and $1.2 \mathrm{ppm}$ (Appendix A). The highest values (5.9 to 54.2 $\mathrm{ppm}$ ) occur in till overlying the deposit. Slightly elevated Bi values, between 2.8 and $7.6 \mathrm{ppm}$, are found as far as $8 \mathrm{~km}$ southeast from the deposit. Bismuth displays strong $(r>0.8)$ positive correlation with $\mathrm{W}, \mathrm{Sn}, \mathrm{Cu}$ and $\mathrm{In}$, and moderate $(\mathrm{r}=0.6-0.8)$ correlations with $\mathrm{Te}, \mathrm{Pb}, \mathrm{Zn}, \mathrm{Ag}$, As, and $\mathrm{Cd}$ (Table 2).

\section{Arsenic, zinc, and cadmium} in the $<0.063 \mathrm{~mm}$ fraction of till

Arsenic concentrations in till in the study area range from 10 to $745 \mathrm{ppm}$. Background values vary between 10 and $92 \mathrm{ppm}$ (Appendix A). The highest values occur in till that overlies the deposit (225 to $537 \mathrm{ppm}$ ) or Tetagouche Group sedimentary rocks one $\mathrm{km}$ southeast of the deposit (257 to $745 \mathrm{ppm})$. Slightly elevated As values up to 119 ppm occur up to $8 \mathrm{~km}$ southeast from the deposit, as well as northeast overlying Tetagouche Group rocks. Arsenic displays moderate $(\mathrm{r}=0.6-0.8)$ correlations with $\mathrm{Sn}, \mathrm{Cu}, \mathrm{Pb}, \mathrm{Te}$, In, and Bi (Table 2).

Zinc concentrations in till range from 48 to $261 \mathrm{ppm}$. Background values in till up ice vary between 64 and 130 ppm (Appendix A). The highest values occur in till over the deposit (239 to $261 \mathrm{ppm}$ ) and $2 \mathrm{~km}$ southwest of the deposit (247 ppm, sample CS-T09). Slightly elevated Zn values (98 to $177 \mathrm{ppm}$ ) occur in till over Tetagouche Group sedimentary rocks southeast and northeast of the deposit (McClenaghan et al. 2013b). Zinc displays strong ( $r>0.8)$ positive correlation with $\mathrm{Cd}$, In, and $\mathrm{Pb}$, and moderate $(\mathrm{r}=0.6-0.8)$ 


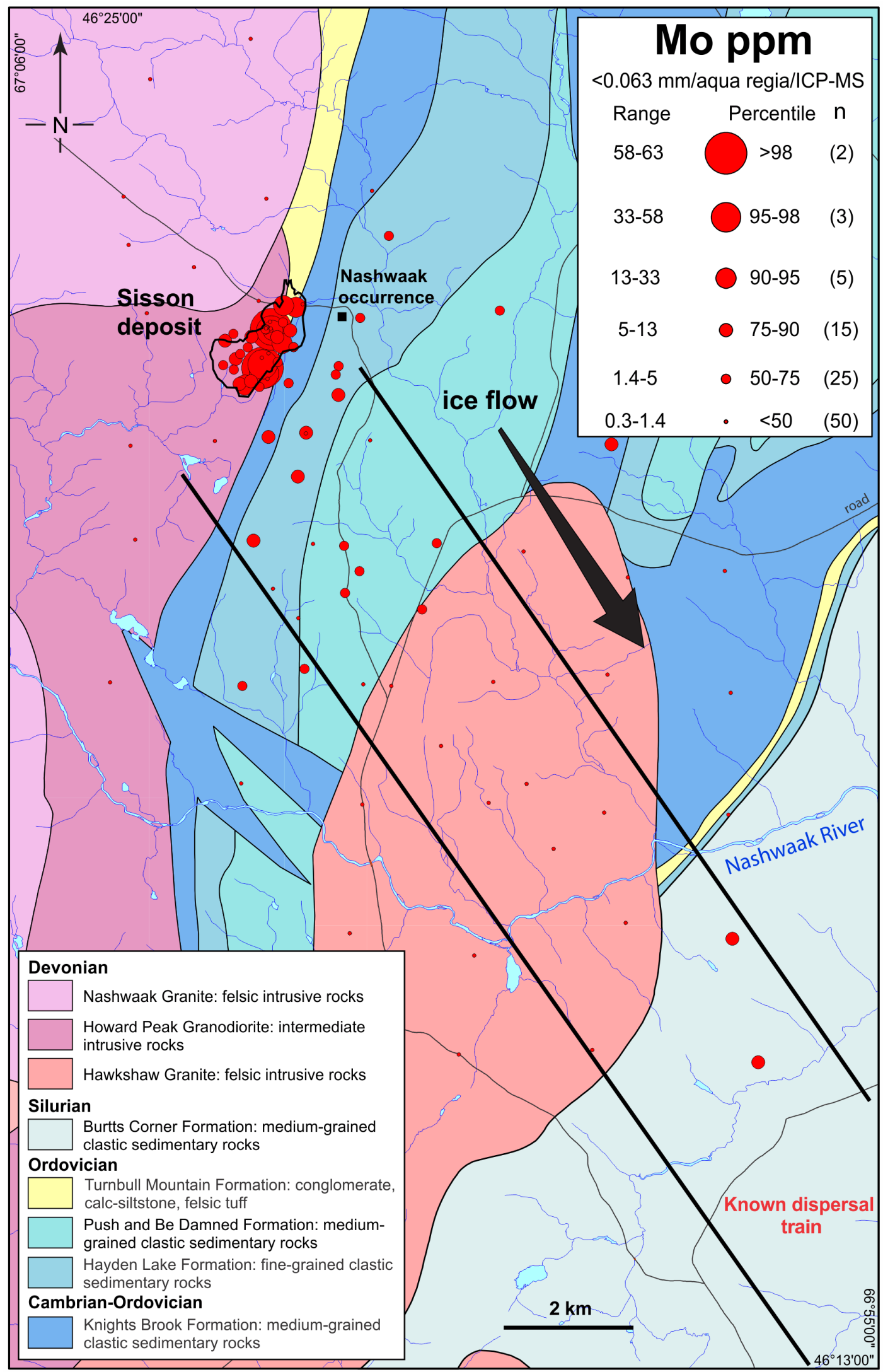

Figure 8. Proportional dot map of Mo (aqua regia/ICP-MS) abundance in the $<0.063 \mathrm{~mm}$ fraction of surface till samples around the Sisson W-Mo deposit. Bedrock geology modified from Smith and Fyffe (2006a-d). Deposit outline in black is from Rennie et al. (2013) (modified from McClenaghan et al. 2013a). 


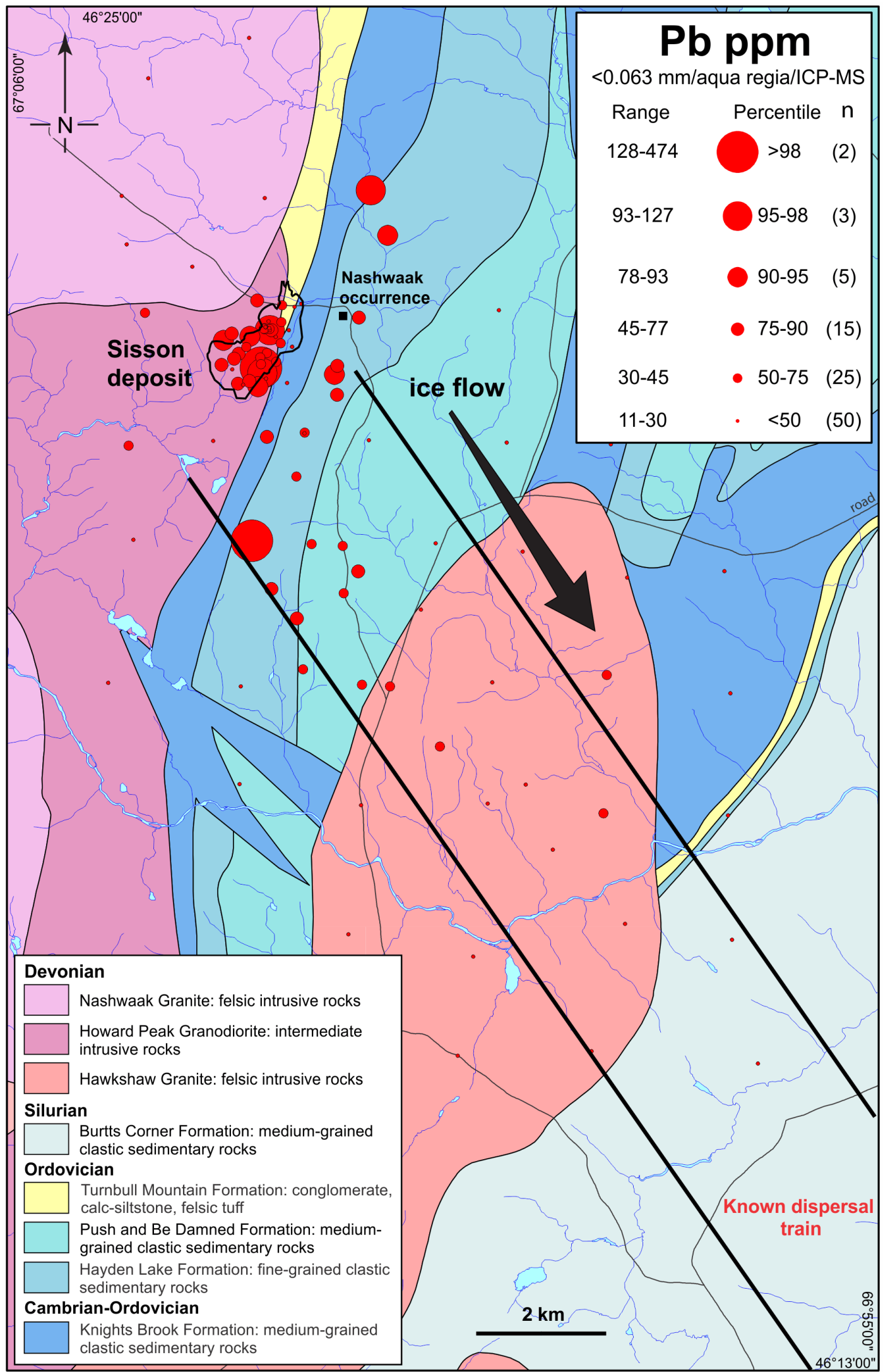

Figure 9. Proportional dot map of $\mathrm{Pb}$ (aqua regia/ICP-MS) abundance in the $<0.063 \mathrm{~mm}$ fraction of surface till samples around the Sisson W-Mo deposit. Bedrock geology modified from Smith and Fyffe (2006a-d). Deposit outline in black is from Rennie et al. (2013) (modified from McClenaghan et al. 2013a). 
correlations with $\mathrm{W}, \mathrm{Sn}, \mathrm{Cu}, \mathrm{Ag}, \mathrm{Bi}$, and $\mathrm{Te}$ (Table 2).

Cadmium concentrations in till range from 0.06 to 1.79 $\mathrm{ppm}$. Background values up ice range between 0.06 and $0.32 \mathrm{ppm}$ (Appendix A). Similar to Zn, till $2 \mathrm{~km}$ southwest of the deposit contains the highest contents of $\mathrm{Cd}$ (1.79 ppm, sample CS-T09). Other significantly elevated values ( 0.80 to $0.92 \mathrm{ppm}$ ) occur in till over the deposit. Cadmium displays strong $(r>0.8)$ positive correlation with $\mathrm{Zn}$, and moderate $(\mathrm{r}=0.6-0.8)$ correlations with $\mathrm{W}, \mathrm{Sn}, \mathrm{Cu}, \mathrm{Ag}, \mathrm{Pb}$, $\mathrm{Ag}, \mathrm{Bi}$, and In (Table 2).

Silver, lead, indium, and tellurium in the $<0.063 \mathrm{~mm}$ fraction of till

Background Ag contents in till up ice vary between 8 and $313 \mathrm{ppb}$ Ag (Appendix A). The highest Ag contents in till are 2 to $3 \mathrm{~km}$ southeast of the deposit (708 ppb; $557 \mathrm{ppb}$ ). The Ag content in till overlying the deposit varies between 24 and $520 \mathrm{ppb}$. Other significantly elevated values (181 to $480 \mathrm{ppb}$ ) occur in till over Tetagouche Group sedimentary rocks southeast of the deposit. Silver displays moderate $(\mathrm{r}=0.6-0.8)$ correlations with $\mathrm{W}, \mathrm{Sn}, \mathrm{Cu}, \mathrm{Pb}, \mathrm{Zn}, \mathrm{As}, \mathrm{Cd}, \mathrm{Bi}$, and In (Table 2).

Lead concentrations in till range from 11 to $474 \mathrm{ppm}$ (Fig. 9). Background values up ice range from 23 to 126 ppm (Appendix A). The maximum $\mathrm{Pb}$ value of $474 \mathrm{ppm}$ is in till collected $2 \mathrm{~km}$ south of the deposit overlying Tetagouche Group rocks. The next highest $\mathrm{Pb}$ value is in till over the deposit (213 ppm). Slightly elevated values of $\mathrm{Pb}$ in till occur over the deposit as well as over Cambrian and Ordovician sedimentary rocks southeast and northeast of the deposit. Lead displays a strong $(r>0.8)$ positive correlation with $\mathrm{Zn}$ and moderate $(\mathrm{r}=0.6-0.8)$ correlations with
$\mathrm{Sn}, \mathrm{Cu}, \mathrm{Ag}, \mathrm{As}, \mathrm{Cd}, \mathrm{Bi}$, and In (Table 2).

Indium contents in till vary from $<0.02$ to $0.41 \mathrm{ppm}$. Background In values in till up ice range from 0.03 to 0.08 ppm (Appendix A). The highest In value of $0.41 \mathrm{ppm}$ occurs in till overlying the southeast part of the deposit. The second highest In value is in till overlying Ordovician sedimentary rocks, $0.7 \mathrm{~km}$ southeast of the deposit $(0.32 \mathrm{ppm})$. Slightly elevated values of In in till (0.08 to 0.28 ) occur over the deposit as well as over Cambrian and Ordovician sedimentary rocks southeast, east, and northeast of the deposit. Indium displays strong $(r>0.8)$ positive correlations with $\mathrm{Sn}, \mathrm{Cu}, \mathrm{Zn}$, and $\mathrm{Bi}$, and moderate $(\mathrm{r}=0.6-0.8)$ correlations with $\mathrm{W}, \mathrm{Pb}, \mathrm{Ag}, \mathrm{As}, \mathrm{Cd}$, and Te (Table 2).

Till in the Sisson area contains between $<0.02$ and 0.89 ppm Te. Background values up ice of the deposit are $<0.02$ to $0.05 \mathrm{ppm}$ (Appendix A). The highest values of 0.51 to $0.89 \mathrm{ppm}$ are in till directly overlying mineralization. Slightly elevated values of Te $(0.05-0.20 \mathrm{ppm})$ occur in till over the deposit as well as over Cambrian and Ordovician sedimentary rocks southeast and northeast of the deposit. Tellurium displays a strong $(r>0.8)$ positive correlation with $\mathrm{Cu}$, and moderate $(\mathrm{r}=0.6-0.8)$ correlations with $\mathrm{W}, \mathrm{Sn}$, Mo, Zn, As, In, and Bi (Table 2).

\section{DISCUSSION}

\section{Glacial Dispersal Patterns}

The highest concentrations of $\mathrm{W}$ and $\mathrm{Mo}$ in the $<0.063$ $\mathrm{mm}$ fraction of till detected in this study overlie the Sisson deposit. Elevated W and Mo values in till form a continuous 3 to $5 \mathrm{~km}$-long southeast-trending dispersal train but are also detected at least $10 \mathrm{~km}$ southeast of the deposit.

\begin{tabular}{|c|c|c|c|c|}
\hline Sample & Interpretation & $\begin{array}{c}\text { distance from } \\
\text { deposit (m) }\end{array}$ & $\begin{array}{c}\mathrm{W} \\
\mathrm{ppm}\end{array}$ & $\begin{array}{r}\text { Mo } \\
\text { ppm }\end{array}$ \\
\hline 11-MPB-520 & background up ice & -4000 & 6 & 0.5 \\
\hline 11-MPB-507 & overlying mineralization & 0 & 816 & 63.0 \\
\hline 11-MPB-568 & overlying mineralization & 0 & 325 & 58.3 \\
\hline 11-MPB-573 & overlying mineralization & 0 & 393 & 36.4 \\
\hline 11-MPB-574 & proximal down ice & 20 & 42 & 4.5 \\
\hline 11-MPB-502 & proximal down ice & 50 & 48 & 1.6 \\
\hline CS-W08.5 & proximal down ice & 650 & 51 & 3.5 \\
\hline 11-MPB-544 & proximal down ice & 1000 & 75 & 8.3 \\
\hline 11-MPB-519 & distal down ice & 1100 & 41 & 8.0 \\
\hline CS-VW09.5 & distal down ice & 1500 & 26 & 5.4 \\
\hline 11-MPB-546 & distal down ice & 2500 & 16 & 1.0 \\
\hline CS-W10A & distal down ice & 3200 & 14 & 2.0 \\
\hline 11-MPB-526 & distal down ice & 3600 & 13 & 1.6 \\
\hline 11-MPB-525 & distal down ice & 4300 & 22 & 1.6 \\
\hline CS-WX11.5-2 & distal down ice & 6200 & 11 & 1.1 \\
\hline 11-MPB-539 & distal down ice & 10000 & 13 & 0.9 \\
\hline 11-MPB-540 & distal down ice & 13000 & 4 & 6.0 \\
\hline
\end{tabular}


This pattern trending southeast is expected as the till sampling was biased to sites within the first $14 \mathrm{~km}$ of the known southeast-trending dispersal train. The $\mathrm{W}$ and Mo values for till samples reported in Table 3 offer a guide to metal contents in till versus distance from the deposit.

The glacial dispersal patterns for $\mathrm{Zn}$ and $\mathrm{Cd}$ are different from $\mathrm{W}$ and $\mathrm{Mo}$ in that values of $\mathrm{Zn}$ and $\mathrm{Cd}$ are highest over the deposit as well as in one sample that is $2 \mathrm{~km}$ southwest of the deposit. Slightly elevated values of 98-128 ppm $\mathrm{Zn}$ and $0.25-0.66 \mathrm{ppm}$ Cd overlie Tetagouche Group volcanic and sedimentary rocks northeast and south of the deposit, but not immediately southeast of the deposit where $\mathrm{W}$ and Mo values are elevated. Patterns for $\mathrm{Pb}$ (Fig. 9), Ag, In, and $\mathrm{Te}$ are similar to those for $\mathrm{Zn}$ and $\mathrm{Cd}$. The bedrock source of elevated concentrations of $\mathrm{Pb}, \mathrm{Cu}, \mathrm{Te}$, and to a lesser extent $\mathrm{Zn}$, In, and Ag, in till east and northeast of the deposit may be (1) a more distal expression of the intrusion that formed the Sisson deposit, such as the Nashwaak occurrence, or (2) metal-rich Ordovician Tetagouche Group sedimentary rocks that are unrelated to the intrusion mineralized system. These elevated metal concentrations in till east-northeast of the deposit warrant further investigation to determine their bedrock source.

Although the highest $\mathrm{Sn}$ values occur in till overlying and immediately down ice of the deposit and form a weak southeast-trending dispersal train, Sn contents in till are relatively low, varying between 3 to $28 \mathrm{ppm}$. In contrast, Sn content in till overlying the subcropping mineralization of the Mount Pleasant W-Mo-Sn-In deposit $100 \mathrm{~km}$ to the south is 150 to $409 \mathrm{ppm}$ (GSC unpublished data). The low Sn content in till at the Sisson deposit is not unexpected as Sn minerals have not been reported in the deposit. Tin is therefore not a pathfinder element for the Sisson deposit.

\section{Source of High Metal Contents in Till}

The Sisson deposit contains an estimated resource of 383 Mt at $0.069 \% \mathrm{WO}_{3}$ (Rennie et al. 2013); thus, it is not unexpected for glacial debris eroded from the deposit to contain significant (100s ppm) W contents (Appendix A). Till samples that contain the highest W contents in the $<0.063 \mathrm{~mm}$ fraction at the Sisson deposit also contain up to 150,000 scheelite grains $/ 10 \mathrm{~kg}$ in the pan concentrate fraction (Appendix A), with most grains between 25 and $200 \mu \mathrm{m}$ in size (McClenaghan et al. 2013a, c). Only one till sample in this study was found to contain wolframite (McClenaghan et al. 2013a, c). Thus, it is most likely that scheelite is the source of much of the $\mathrm{W}$ in till samples in this study. Rennie et al. (2013) reported that the Sisson deposit also has a significant grade of Mo $(0.023 \%)$, which is hosted in molybdenite and Mo-rich scheelite (molybdo-scheelite). These two minerals are the likely sources of the 10s ppm Mo in till overlying the deposit and down ice.

The Sisson deposit contains significant chalcopyrite, as do till samples overlying and down ice of the deposit (McClenaghan et al. 2013a, c), thus, chalcopyrite is the likely source of elevated $\mathrm{Cu}$ in metal-rich till around the Sisson deposit. Elevated Bi content in till (10s of ppm) is likely hosted in the Bi-rich minerals native bismuth (Bi), bismuthinite $\left(\mathrm{Bi}_{2} \mathrm{~S}_{3}\right)$, bismutite $\left(\mathrm{Bi}_{2}\left(\mathrm{CO}_{3}\right) \mathrm{O}_{2}\right)$, and joseite $\left(\mathrm{Bi}_{4}(\mathrm{~S}, \mathrm{Te})_{3}\right)$ that were recovered from the heavy mineral fraction of metal-rich till samples overlying and up to $4 \mathrm{~km}$ down ice (southeast) of the deposit (McClenaghan et al. 2013a, c). Sphalerite is a minor mineral in the deposit, and is likely the source of elevated $\mathrm{Zn}$ (100s of ppm), as well as Cd and In in till overlying the deposit. Cadmium and In are known to occur in sphalerite (Cook et al. 2009; Pfaff et al. 2011). The source of elevated $\mathrm{Pb}(100-400 \mathrm{ppm})$ contents in till is likely galena, which was observed in the mineralized zones by Nast and Williams-Jones (1991). Silver-bearing minerals in the deposit include hessite $\left(\mathrm{Ag}_{2} \mathrm{Te}\right)$ and acanthite $\left(\mathrm{Ag}_{2} \mathrm{~S}\right)$ (Nast and Williams-Jones 1991) and these minerals may be the source of elevated Ag in till overlying the deposit. Arsenopyrite was recovered from the heavy mineral fraction of metal-rich till in this study (McClenaghan et al. 2013a, c) and is the most likely source of the highest As values in till. Elevated values of Te in till over the deposit are likely related to the presence of the Te-bearing minerals hessite and joseite (Table 1) in the mineralization. The source of the low levels of Sn (10s of ppm) in the till could be rare cassiterite grains in the mineralization, though no cassiterite or any other Sn-bearing minerals have been seen in the Sisson deposit rocks used in this study or in any other studies of the deposit.

\section{Indicator and Pathfinder Elements}

The term 'indicator element' is used here to refer to an element that is an economically valuable component of the ore being sought and which may be used to detect an orebody (Rose et al. 1979). The results reported here indicate that $\mathrm{W}$ is the optimal indicator element for the Sisson deposit. Molybdenum is also an indicator, but to a much lesser extent. The term 'pathfinder element' is used here to refer to non-ore elements associated with the orebody that may be used to detect the orebody (Rose et al. 1979). Pathfinder elements in till overlying and down ice of the Sisson deposit include $\mathrm{Cu}, \mathrm{Zn}, \mathrm{Pb}, \mathrm{Ag}, \mathrm{Bi}, \mathrm{In}, \mathrm{As}, \mathrm{Cd}, \mathrm{Zn}$, and $\mathrm{Te}$. This list of elements is more extensive than the list of elements (W, Mo, Cu, As, and F) that Snow and Coker (1987) and Lamothe (1992) identified as key indicator/pathfinder elements in their earlier till geochemical study of the Sisson deposit. The Sisson indicator/pathfinder element suite identified in this study is also more extensive than those identified in other published studies around $\mathrm{W}$ mineralization (Table 4), which variably include $\mathrm{Mo}, \mathrm{Sn}, \mathrm{As}, \mathrm{Cu}$, $\mathrm{Bi}$, and $\mathrm{Pb}$ (e.g., Matilla and Peuraniemi 1980; Tuach 1988; Rogers et al. 1990; Peuraniemi 1992). The extensive suite of indicator/pathfinder elements identified at Sisson reflects, in part, the polymetallic nature of the deposit as well as the ability of modern ICP-MS techniques to determine a broader suite of elements at lower detection limits. 
Table 4. Other published till/soil studies around known W mineralization in glaciated terrain and regional till surveys that reported significant $\mathrm{W}$ data.

\begin{tabular}{|c|c|c|c|c|c|c|}
\hline Country & $\begin{array}{c}\text { Indicator and } \\
\text { pathfinder elements }\end{array}$ & $\begin{array}{l}\text { Sample } \\
\text { medium }\end{array}$ & $\begin{array}{l}\text { Analytical fraction used } \\
\text { for tungsten analysis }\end{array}$ & $\begin{array}{l}\text { Maximum W content in } \\
\text { silt+clay ( or similar size) } \\
\text { fraction }(\mathrm{ppm})\end{array}$ & Analytical methods & Source of information \\
\hline Sweden & $\mathrm{W}$ & till & $<0.5 \mathrm{~mm} ;>3.31 \mathrm{SG}$ & not reported & XRF spectrometry & Brundin and Bergstrom (1977) \\
\hline Canada & $\mathrm{W}$ & till & $\begin{array}{c}>3.3 \text { SG HMC; }<2.0 \mathrm{~mm} ; \\
<0.075 \mathrm{~mm}\end{array}$ & 220 & fusion/colourimetry & Coker et al. (1988) \\
\hline Finland & $\mathrm{W}, \mathrm{Sn}, \mathrm{Mo}, \mathrm{Cu}$ & till & $<0.06 \mathrm{~mm}$ & not reported & AAS & Matilla and Peuraniemi (1980) \\
\hline Finland & $\mathrm{W}$ & till & $<0.062 \mathrm{~mm}$ & $>10$ & not reported & Nikkarinen and Björklund (1976) \\
\hline Norway & $\mathrm{W}$ & soil & $<0.25 \mathrm{~mm}$; HMC & $<5$ & $\begin{array}{c}<0.25 \text { by colourimetry; } \\
\text { HMC by XRF }\end{array}$ & Petersen and Stendal (1987) \\
\hline Finland & $\mathrm{W}$ & till & $<0.06 \mathrm{~mm}$ & 1028 & $4 \mathrm{acid} / \mathrm{AAS}$ & Peuraniemi (1992) \\
\hline Finland & Sn & till & HMC & not reported & $\mathrm{XRF}$ & Peuraniemi and Heinänen (1985) \\
\hline Canada & $\mathrm{W}, \mathrm{Sn}$ & till & $0.063-0.30 \mathrm{~mm}$ & $>2000$ & fusion/colourimetry & Stea (1982) \\
\hline Canada & $\mathrm{W}, \mathrm{Sn}$ & till & $0.063-0.30 \mathrm{~mm}>2.96 \mathrm{SG}$ & clay+silt not analyzed & fusion/colourimetry & Stea and O'Reilly (1982) \\
\hline Ireland & $\mathrm{W}$ & soil & not reported & 80 & not reported & Steiger (1977) \\
\hline Sweden & W, Mo & till & $\begin{array}{c}<0.5 \mathrm{~mm}>2.96 \mathrm{SG} ;<0.1 \\
\mathrm{~mm} ; 0.1-0.5 \mathrm{~mm}\end{array}$ & 105 & not reported & Toverud (1984) \\
\hline Canada & $\mathrm{W}$ & soil & not reported & $>250$ & not reported & Tuach (1988) \\
\hline Canada & $\mathrm{W}, \mathrm{Cu}, \mathrm{Zn}$ & till & not reported & not reported & not reported & Rogers et al . (1990) \\
\hline Canada & $\mathrm{W}, \mathrm{Cu}, \mathrm{Pb}, \mathrm{Zn}, \mathrm{Mo}$ & till & $<0.002 \mathrm{~mm}$ & 1600 & colourimetry & Lamothe (1992) \\
\hline Canada & $\mathrm{W}, \mathrm{Mo}, \mathrm{As}, \mathrm{Bi}, \mathrm{Pb}$ & till & $<0.063 \mathrm{~mm}$ & 75 & INAA & Seaman (2003) \\
\hline Canada & $\begin{array}{l}\mathrm{W}, \mathrm{Mo}, \mathrm{Bi}, \mathrm{Cu}, \mathrm{Pb} \\
\mathrm{Zn}, \mathrm{Ag}, \mathrm{Te}\end{array}$ & till & $<0.063 \mathrm{~mm}$ & 816 & borate fusion/ICP-MS & This study \\
\hline
\end{tabular}

Note: $\mathrm{HMC}=$ heavy mineral concentrate. $\mathrm{NA}=$ not analyzed

\section{Comparison of Tungsten Content of Till to Other Studies and Deposits}

The highest $\mathrm{W}$ value reported for $<0.063 \mathrm{~mm}$ till fraction in this study is $816 \mathrm{ppm}$. This value is slightly lower than the maximum value of $1200 \mathrm{ppm}$ reported for the $<0.075$ $\mathrm{mm}$ till fraction at the Sisson deposit by Snow and Coker (1987). Seaman and McCoy (2008) report a similar maximum $(1240 \mathrm{ppm})$ for one till sample they collected from the 2007 exploration trench. Other till/soil studies around known $\mathrm{W}$ mineralization in glaciated terrain and regional till surveys that reported significant $\mathrm{W}$ data are compared in Table 4. The values in this table indicate that significant $\mathrm{W}$ values in till around $\mathrm{W}$ mineralization can vary from a few $100 \mathrm{ppm}$ to $2000 \mathrm{ppm}$.

\section{Till Size Fractions and Analytical Methods}

Some of the earliest till geochemical studies around $\mathrm{W}$ mineralization analyzed the heavy mineral fraction of till to determine its $\mathrm{W}$ content because scheelite is a heavy mineral and would be concentrated in this fraction if present in the till (Toverud 1984; Peuraniemi and Heinänen1985; Petersen and Stendal 1987; Coker et al. 1988; Snow and Coker 1987). Some early studies also used the $<0.063 \mathrm{~mm}$ fraction (Table 4) to successfully detect or model glacial dispersal of W-rich debris from mineralization (e.g., Nikkarinen and Björklund 1976; Johansson et al. 1986; Salminen and Hartikainen 1986; Petersen and Stendal 1987; Peuraniemi 1992). The $<0.063 \mathrm{~mm}$ fraction of till was analyzed in this study to evaluate if this commonly used size fraction (e.g., Pronk and Burton 1988; Batterson 1989; Lestinen et al. 1991; Koljonen 1992; Friske et al. 2001; McClenaghan et al. 2011) is suitable for W-Mo exploration in the region and to allow for comparison with the previous NBDEM regional till surveys in the Sisson area. The results presented here, combined with earlier results reported by Seaman $(2003,2012)$, confirm that the $<0.063 \mathrm{~mm}$ fraction of till reflects dispersal up to $40+\mathrm{km}$ down ice (southeast) of the Sisson deposit and is suitable for W-Mo exploration in the Sisson region.

Most published reports describing the use of till geochemistry for $\mathrm{W}$ exploration were published between the 1970s and early 1990s. In these studies, samples were analyzed using X-ray fluorescence spectrometry or a combination of a fusion or sintering digestion followed by measurement by colourimetry (e.g., Snow and Coker 1987; Petersen and Stendal 1987; Coker et al. 1988; Lamothe 1992). Lestinen et al. (1991) determined W contents using a $10 \mathrm{M} \mathrm{HCl}$ leach and measurement by spectrophotometer. These older methods were highly specialized, required a separate and unique method just to determine $\mathrm{W}$, and added to the cost of routine analytical methods used for other elements. 
Analytical methods for $\mathrm{W}$ have improved significantly in the past 30 years. With the development of ICP-MS techniques and improvements in lower detection limits for ICPMS and instrumental neutron activation analysis (INAA) over the past 20 years, the determination of the $\mathrm{W}$ content in till is now routine and inexpensive. An analytical technique that reports the total content of $\mathrm{W}$ is necessary for till analysis because aqua regia does not fully digest W-bearing oxides. In this study, lithium tetra/metaborate fusion followed by nitric digestion/ICP-MS was used to determine the total $\mathrm{W}$ content of till samples. The other indicator and pathfinder elements listed above were determined by aqua regia digestion as they occur in sulphide and telluride minerals (Table 1) that are more easily digested by aqua regia.

\section{CONCLUSIONS}

This till geochemical study is the first detailed study around a major $\mathrm{W}$ deposit in glaciated terrain. Combined with the earlier work of Snow and Coker (1987), Lamothe (1992) and NBDEM (Seaman 2002, 2003; Seaman and McCoy 2008) around the Sisson W-Mo deposit, they define glacial dispersal of W pathfinder elements at least $40 \mathrm{~km}$ down ice to the southeast. The $\mathrm{W}$ and Mo values for the $<0.063 \mathrm{~mm}$ fraction of till samples reported in Table 3 offer a guide to metal contents that might be expected versus distance from a $\mathrm{W}$-mineralized source. In general, $\mathrm{W}$ and Mo contents in till decrease with increasing distance down ice of the deposit, as has been noted by Shilts (1996), DiLabio (1990) and many others for glacial ice dispersal from specific bedrock sources. Overlying the deposit, metal-rich till contains up to $816 \mathrm{ppm} \mathrm{W}$ and $63 \mathrm{ppm} \mathrm{Mo}$, while at 1 $\mathrm{km}$ down ice till contains up to $75 \mathrm{ppm} \mathrm{W}$ and $8 \mathrm{ppm} \mathrm{Mo.}$ Till in background areas contains 3-7 ppm W and 0.4-1.7 ppm Mo.

Indicator elements for this type of W-Mo deposit are the main ore elements $\mathrm{W}$ and Mo. Pathfinder elements identified in this study include $\mathrm{Ag}, \mathrm{As}, \mathrm{Bi}, \mathrm{Cd}, \mathrm{Cu}, \mathrm{In}, \mathrm{Pb}, \mathrm{Te}$, and $\mathrm{Zn}$; a list more extensive than $\mathrm{Cu}$, As, and $\mathrm{F}$ identified by Snow and Coker (1987), and more extensive than those identified in other published studies around W mineralization. The extensive suite of indicator + pathfinder elements identified at Sisson reflects the polymetallic nature of the deposit and the broader suite of elements that is now available using modern ICP-MS techniques. A total digestion method is required to determine the total concentration of $\mathrm{W}$ in till, either lithium tetra/metaborate fusion followed by nitric digestion/ICP-MS or instrumental neutron activation analysis (INAA). Aqua regia/ICP-MS is a suitable method for determining the other elements. Glacial dispersal of W and Mo from the Sisson deposit is detectable using regional-scale surface till sampling at least $10 \mathrm{~km}$ down ice (southeast). The $2 \mathrm{~km}$ sample spacing, used by the NBDEM for its regional till sampling program, is sufficiently dense to detect the $\mathrm{W}$ dispersal train from the Sisson deposit as well as its polymetallic nature. This study also identified an area of elevated metal content in till east of the Sisson deposit overlying Ordovician rocks of the Tetagouche Group that warrants further investigation. The bedrock source of the elevated metal contents may be related to the Nashwaak polymetallic occurrence $900 \mathrm{~m}$ east of the Sisson deposit, or other unknown metal-rich rocks in the area.

\section{ACKNOWLEDGEMENTS}

The Sisson deposit case study was conducted as part of the Geological Survey of Canada's Targeted Geoscience Initiative 4 (TGI-4). This study is a collaborative research effort between the Geological Survey of Canada and the New Brunswick Department of Energy and Mines. Rob Duncan, Kandi Gallagher, Will Gilmore, Jim Lang, Megan Little, Charlie Morrisey, Drew Takahashi, and Alexandra Shaw of HDI and Northcliff Resources Limited are thanked for sharing confidential geological information, providing access to the deposit, facilitating field work, and providing bedrock samples. Kathleen Thorne is thanked for discussions of the bedrock and deposit geology. Jessey Rice, Brock University, and Mike Richards, University of New Brunswick, are thanked for their able field assistance. Sarah Hashmi, University of Waterloo, contributed to this study by conducting a literature review of till geochemical studies related to W-Mo glacial dispersal and a preliminary assessment of a small subset of the GSC till geochemical data as part of her B.Sc. thesis. Gwendy Hall (Emeritus Scientist, Geological Survey of Canada) provided guidance on analytical methods. Bill Coker's early work in the 1980s at the Sisson deposit and his more recent advice (2011) are key factors to the success of the study reported here. This paper is dedicated to Bill's memory. Journal reveiwers Mike Parsons and Chantel Nixon are thanked for their comments which improved the manuscript. Geological Survey of Canada Contribution No. 20130510.

\section{REFERENCES}

Aario, R. and Peuraniemi, V. 1992. Glacial dispersal of till constituents in morainic landforms of different types. Geomorphology, 6, pp. 9-25. http://dx.doi. org/10.1016/0169-555X(92)90044-O

Batterson, M.J. 1989. Glacial dispersal from the Strange Lake alkalic complex, northern Labrador. In Drift Prospecting. Edited by R.N.W. DiLabio and W.B. Coker. Geological Survey of Canada, Paper 89-20, pp. 31-40.

Brundin, N.H. and Bergstrom, J. 1977. Regional prospecting for ores based on heavy minerals in glacial till. Journal of Geochemical Exploration, 7, pp. 1-19. http:// dx.doi.org/10.1016/0375-6742(77)90071-1

Coker, W.B., Robertson J., and Snow, R.J. 1988. Till geochemistry at the Great Gull scheelite prospects, Newfoundland, Canada: A case history in orientation and discovery. In Prospecting in Areas of Glaciated Terrain-1988. Canadian Institute of Mining and Metallurgy, pp. 587-598. 
Cook, N.J., Ciobanu, C.L., Pring, A., Skinner, W., Shimizu, M., Danyushevsky, L., Saini-Eidukat, B., and Melcher, F. 2009. Trace and minor elements in sphalerite; a LA-ICPMS study. Geochimica et Cosmochimica Acta, 73, pp. 4761-4791. http://dx.doi.org/10.1016/j. gca.2009.05.045

DiLabio, R.N.W. 1982. Gold and tungsten abundances vs. grain size in till at Waverley, Nova Scotia. In Current Research, Part B, Geological Survey of Canada, Paper 821B, pp. 57-62.

DiLabio, R.N.W. 1990. Glacial dispersal trains. In Glacial Indicator Tracing. Edited by R. Kujansuu and M. Saarnisto. A.A. Balkema, Rotterdam, pp.109-122.

DiLabio, R.N.W. 1995. Residence sites of trace elements in oxidized tills. In Drift Exploration in the Canadian Cordillera. Edited by P.T. Bobrowsky, S.J. Sibbick, J.M. Newell, and P.F. Matysek. British Columbia Ministry of Energy, Mines and Petroleum Resources, Paper 1995-2, pp. 139-148.

Friske, P.W.B., McCurdy, M.W., Day, S.J.A., and McNeil, R.J. 2001. Evaluation of partial and selective leach data from humus, B-horizon and till: a case study from the Clarence Stream gold property, southern New Brunswick. In Current Research, Geological Survey of Canada, Mineral Resource Report 2001-4, pp. 25-45.

Fyffe, L.R., Thorne, K., Dunning, G.R., and Martin, D.A. 2008. U-Pb geochronology of the Sisson Brook granite porphyry, York County, west-central New Brunswick. In Geological Investigations in New Brunswick for 2007. Edited by G.L. Martin. New Brunswick Department of Natural Resources; Minerals, Policy and Planning Division, Mineral Resource Report 2008-1, pp. 35-54.

Fyffe, L.R., Seaman, A., Thorne, K., and Martin, D.A. 2010. Part 1: Sisson Brook W-Mo-Cu deposit. In Polymetallic deposits of Sisson Brook and Mount Pleasant, New Brunswick, Canada. Compiled by L.R. Fyffe and K. Thorne, K. New Brunswick Department of Natural Resources, Field Guide No. 3, pp. 7-33.

Johansson, K., Keinänen, V., and Lehmuspelto, P. 1986. Geochemical exploration for tungsten in glaciogenic deposits in Soretiapulju, Western Finnish Lapland. In Prospecting in Areas of Glaciated Terrain. Institute of Mining and Metallurgy. pp. 61-68.

Koljonen, T. 1992. The Geochemical Atlas of Finland Part 2: Till. Geological Survey of Finland, Espoo, Finland, $218 \mathrm{p}$.

Lamothe, M. 1992. Pleistocene stratigraphy and till geochemistry of the Miramichi Zone, New Brunswick. Geological Survey of Canada, Bulletin 433, 58 p. http:// dx.doi.org/10.4095/183878

Lestinen, P., Kontas, E., Niskavaara, H., and Virtasalo, J. 1991. Till geochemistry of gold, arsenic and antimony in the Seinäjoki district, western Finland. Journal of Geochemical Exploration, 39, pp. 343-361. http://dx.doi. org/10.1016/0375-6742(91)90021-L

Lynch, J.J. 1996. Provisional elemental values for four new geochemical soil and till reference materials, TILL-I, TILL-2, TILL-3 and TILL-4. Geostandards Newsletter, 20, pp. 277-287. http://dx.doi.org/10.1111/j.1751908X.1996.tb00189.x

Marr, J. M. 2009. Sisson Brook tungsten molybdenum deposit, New Brunswick, preliminary economic assessment (2009 Technical and Economic Update), September 16th, 2009. National Instrument 43-101 technical report by Geodex Minerals Ltd., 106 p.

Matilla, E. and Peuraniemi, V. 1980. On geochemical prospecting for tin in southern Finland. In Methods of the Geochemical Mapping and Boulder Prospecting in the Eastern Part of the Baltic Shield. Geological Survey of Finland, Espoo, Finland, pp. 133-158.

McClenaghan, M.B., Layton-Matthews, D., and Matile, G. 2011. Till geochemical signatures of magmatic $\mathrm{Ni}-\mathrm{Cu}$ deposits, Thompson Nickel Belt, Manitoba, Canada. Geochemistry: Exploration, Environment, Analysis, 11, pp. 145-159. http://dx.doi.org/10.1144/1467-7873/09IAGS-021

McClenaghan, M.B., Parkhill, M.A., Seaman, A.A., Pronk, A.G., Averill, S.A., Rice, J.M., and Pyne M. 2013a. Indicator mineral signatures of the Sisson W-Mo deposit, New Brunswick: part 2 till samples. Geological Survey of Canada, Open File 7467, 31 p.

McClenaghan, M.B., Parkhill, M.A., Seaman, A.A., Pronk, A.G., Pyne, M., Rice, J.M., and Hashmi, S. 2013b. Till geochemical signatures of the Sisson W-Mo deposit, New Brunswick. Geological Survey of Canada, Open File 7430, 53 p. http://dx.doi.org/10.4095/292837

McClenaghan, M.B., Parkhill, M.A., Averill, S.A., Pronk, A.G., Seaman, A.A., Boldon, R., McCurdy, M.W., and Rice, J.M. 2013c. Indicator mineral abundance data for bedrock, till, and stream sediment samples from the Sisson W-Mo deposit, New Brunswick. Geological Survey of Canada, Open File 7387, 18 p. http://dx.doi. org/10.4095/292670

McClenaghan, M.B., Plouffe, A., McMartin, I., Campbell J.E., Spirito, W.A., Paulen, R.C., Garrett, R.G., and Hall, G.E.M. 2013d. Till sampling and geochemical analytical protocols of the Geological Survey of Canada. Geochemistry: Exploration, Environment, Analysis, 13, pp. 285-301. http://dx.doi.org/10.1144/geochem2011-083

Nast, H.J., and Williams-Jones, A.E. 1991. The role of water-rock interaction and fluid evolution in the forming of the porphyry-related Sisson Brook W-Cu-Mo deposit, New Brunswick. Economic Geology, 86, pp. 302-317. http://dx.doi.org/10.2113/gsecongeo.86.2.30

New Brunswick Department of Energy and Mines. 2013. Nashwaak, Reference Number 209; New Brunswick Department of Energy and Mines Mineral Occurrence Database. URL http://dnre-mrne.gnb.ca/mineraloccurrence/, February 2014.

Nikkarinen, M., and Björklund, A. 1976. Kaustinen: The use of till in tungsten prospecting; Journal of Geochemical Exploration, 21, pp. 247-248. 
Petersen, L.R. and Stendal, H. 1987. Tungsten exploration in the Valnesfjord region, Nordland, northern Norway. Journal of Geochemical Exploration, 29, pp. 151-163. http://dx.doi.org/10.1016/0375-6742(87)90075-6

Peuraniemi, V. 1992. Hieronmaki: W, Sn, Cu and Zn concentrations of till near a scheelite mineralization in hilly region. In Handbook of Exploration Geochemistry: Regolith Exploration Geochemistry in Arctic and Temperate Terrains, Volume 5. Edited by K. Kauranne, R. Salminen, and V-P. Salonen. Elsevier, Espoo, Finland, pp. 277-282.

Peuraniemi, V. and Heinänen, K. 1985. Mineralogical investigations in the interpretation of heavy-mineral geochemical results. Journal of Geochemical Exploration, 23, pp. 315-328. http://dx.doi.org/10.1016/03756742(85)90034-2

Pfaff, K., Koenig, A.E., Wenzel, T., Ridley, I., Hildebrandt, L.H., Leach, D.L., and Markl, G. 2011. Trace and minor element variations and sulfur isotopes in crystalline and colloform ZnS: Incorporation mechanisms and implications for their genesis. Chemical Geology, 286, pp. 118-134.

Pronk, A.G. and Burton, D.M. 1988. Till geochemistry as a technique for gold exploration in northern New Brunswick. Bulletin of the Canadian Institute of Mining and Metallurgy, 81, pp. 90-98.

Rennie, D.W., Firedman, D., Gray, J., Bolu, M., Pozder, S., and Greskovich, G. 2013. Canadian National Instrument 43-101 technical report on the Sisson Project, New Brunswick, Canada, Samuel Engineering Inc., SEDAR website: http://www.sedar.com/DisplayCompanyDocuments.do?lang=ENandissuerNo $=00030606$

Rogers, P.J., Chatterjee, A.K., and Aucott, J.W., 1990. Metallogenic domains and their reflection in regional lake sediment surveys from the Meguma Zone, southern Nova Scotia, Canada. Journal of Geochemical Exploration, 39, pp. 153-174. http://dx.doi.org/10.1016/03756742(90)90072-I

Rose, A.W., Hawkes, H.E., and Webb, J.S. 1979. Geochemistry in Mineral Exploration. Academic Press, London, $657 \mathrm{p}$.

Salminen, R. and Hartikainen, A. 1986. Tracing gold, molybdenum and tungsten mineralization by use of a step by step geochemical study in Ilomantsi, eastern Finland, In Prospecting in Areas of Glaciated Terrain-1986. Institution of Mining and Metallurgy, London, pp. 201-209.

Seaman, A.A. 2001. Preliminary report-till geochemistry of part of the west half of the Coldstream (NTS $21 \mathrm{~J} / 06$ ) map area, Carleton and York counties, New Brunswick. New Brunswick Department of Natural Resources, Open File 2001-2, 51 p.

Seaman, A.A. 2002. Till geochemistry of the central and eastern parts of the Coldstream (NTS $21 \mathrm{~J} / 06$ ) map area, York and Carleton counties, New Brunswick. New Brunswick Department of Natural Resources, Open File 2002-5, 80 p.
Seaman, A.A. 2003. Follow up till geochemistry, Coldstream (NTS21J/06) map area and part of the adjacent Napadogan (NTS 21 J/07) map area, York and Carleton counties, New Brunswick. New Brunswick Department of Natural Resources, Open File 2003-11, 103 p.

Seaman, A.A. 2007. Reconnaissance till geochemistry of NTS $21 \mathrm{~J} / 01, \mathrm{~J} / 02, \mathrm{~J} / 07$, and J/08 map areas (parts of York, Sunbury, Northumberland, and Queens counties), central New Brunswick: site and geochemical data. New Brunswick Department of Natural Resources, Open File 2007-8, 95 p.

Seaman, A.A. 2009. The Appalachian Glacier Complex, and the Middle to Late Pleistocene history of west-central New Brunswick, Canada. In Geological Investigations in New Brunswick for 2008. Edited by G.L. Martin. New Brunswick Department of Natural Resources, Mineral Resource Report 2009 2, pp. 66-140.

Seaman, A.A. 2012. Till geochemistry of the Burtts Corner, Napadogan, and Hayesville map areas (NTS $21 \mathrm{~J} / 02$, $21 \mathrm{~J} / 07$ and $21 \mathrm{~J} / 10$ ) west-central New Brunswick. New Brunswick Department of Natural Resources, Open File 2012-3, 42 p.

Seaman, A.A. and McCoy, S.M. 2008. Multiple Wisconsinan tills in the Sisson Brook exploration trench of Geodex Minerals Ltd., York County, west-central New Brunswick. In Geological Investigations in New Brunswick for 2007. Edited by G.L. Martin. New Brunswick Department of Natural Resources, Minerals, Policy and Planning Division, Mineral Resource Report 2008-1, pp. 1-34.

Seaman, A.A., Stea, R.R., and Allard, S. 2011. The Appalachian Glacier Complex in the Canadian Maritime Provinces during the Illinoian and Wisconsinan. In Proceedings, GeoHydro 2011, Québec, Québec, doc-2097, 8 p.

Shilts, W.W. 1996. Chapter 15, Drift exploration. In Past Glacial Environments, Sediments, Forms and Techniques. Edited by J. Menzies. Butterworth Heinemann, Toronto, pp. 411-439.

Smith, E.A. and Fyffe, L.R. (compilers) 2006a. Bedrock Geology of the Burtts Corner area (NTS 21 J/02), York County, New Brunswick; New Brunswick Department of Natural Resources, Map Plate 2006-3, 1:50 000-scale.

Smith, E.A. and Fyffe, L.R. (compilers) 2006b. Bedrock geology of the Millville area (NTS $21 \mathrm{~J} / 03$ ), York and Carleton counties, New Brunswick. New Brunswick Department of Natural Resources, Map Plate 2006-4, 1:50 000 -scale.

Smith, E.A. and Fyffe, L.R. (compilers) 2006c. Bedrock geology of the Coldstream area (NTS $21 \mathrm{~J} / 06$ ), York and Carleton counties, New Brunswick. New Brunswick Department of Natural Resources, Map Plate 2006-7, 1:50 000-scale.

Smith, E.A. and Fyffe, L.R. (compilers) 2006d. Bedrock geology of the Napadogan area (NTS $21 \mathrm{~J} / 07$ ), York and Carleton counties, New Brunswick. New Brunswick Department of Natural Resources, Map Plate 2006-8, 1:50 000 -scale. 
Snow, R.J. and Coker, W.B. 1987. Overburden geochemistry related to W-Cu-Mo mineralization at Sisson Brook, New Brunswick, Canada: an example of short- and longdistance glacial dispersal. In Geochemical Exploration 1985. Edited by R.G. Garrett. Journal of Geochemical Exploration, 28, pp. 353-368.

Spirito, W.A., McClenaghan, M.B., Plouffe, A., McMartin, I., Campbell, J.E., Paulen, R.C., Garrett, R.G., and Hall, G.E.M. 2011. Till sampling and analytical protocols for GEM Projects: from field to archive. Geological Survey of Canada, Open File 6850, 83 p. http://dx.doi. org/10.4095/288752

Stea, R.R. 1982. Tin and tungsten data from till samples along the Eastern Shore region, Nova Scotia Department of Mines and Energy, Open File Report ME 480, 8 p.

Stea, R.R. and O'Reilly, G.A. 1982. Till geochemistry of the Meguma Terrane in Nova Scotia and its metallogenic implications. Prospecting in Areas of Glaciated Terrain-1982, Canadian Institute of Mining and Metallurgy. St. John's, Newfoundland, pp. 82-104.

Stea, R.R., Seaman, A.A., Pronk, T., Parkhill, M.A., Allard, S., and Utting, D. 2011. Chapter 48: The Appalachian Glacier Complex in Maritime Canada. In Quaternary Glaciations - Extent and Chronology - A Closer Look. Edited by J. Ehlers, P.L. Gibbard, and P.D. Hughes. Developments in Quaternary Science, 15. Elsevier, Amsterdam, pp. 631- 659.
Steiger, R. 1977. Prospecting for lithium and tungsten in Ireland. In Prospecting in Areas of Glaciated Terrain 1977. Institution of Mining and Metallurgy, London, pp. 14-24.

Stewart, H.J., McLeod, M.J., and Thorne, K.G. 2011. Tungsten. New Brunswick Department of Natural Resources, Lands, Minerals and Petroleum Division, Mineral Commodity Profile No. 7, 7 p.

Toverud, Ö. 1984. Dispersal of tungsten in glacial drift and humus in Bergslagen, south central Sweden. Journal of Geochemical Exploration, 21, pp. 261-272. http:// dx.doi.org/10.1016/0375-6742(84)90053-0

Tuach, J. 1988. Tungsten-molybdenum-bismuth in the Granite Lake-Meelpaeg Lake area, Newfoundland: Geochemical signatures in rock and soil. In Prospecting in Areas of Glaciated Terrain-1988. Canadian Institute of Mining and Metallurgy, pp. 531-551.

United States Geological Survey. 2014. Mineral Commodity Summaries. URL http://minerals.usgs.gov/minerals/ pubs/commodity/tungsten/mcs-2014-tungs.pdf, February 2014.

Editorial responsibility: Sandra M. Barr 
Appendix A. Concentrations of seleted elements in the $<0.063 \mathrm{~mm}$ fraction of surface till samples listed by location relative to the Sisson deposit: up ice, proximal up ice (within $200 \mathrm{~m}$ of the deposit), overlying, proximal down ice (within $1000 \mathrm{~m}$ southeast of the deposit), and down ice distal (>1000 m southeast).

\begin{tabular}{|c|c|c|c|c|c|c|c|c|c|c|c|c|c|c|c|}
\hline Sample & Interpretation & $\begin{array}{c}\text { distance from } \\
\text { deposit }(m)\end{array}$ & $\begin{array}{l}\text { No. scheelite } \\
\text { grains in pan }\end{array}$ & $\begin{array}{c}\mathrm{W} \\
\mathrm{ppm}\end{array}$ & $\begin{array}{r}\text { Mo } \\
\text { ppm }\end{array}$ & $\begin{array}{c}\text { Sn } \\
\text { ppm }\end{array}$ & $\begin{array}{r}\mathrm{Cu} \\
\mathrm{ppm}\end{array}$ & $\begin{array}{c}\mathrm{Pb} \\
\mathrm{ppm}\end{array}$ & $\begin{array}{c}\mathrm{Zn} \\
\mathrm{ppm}\end{array}$ & $\begin{array}{c}\text { As } \\
\text { ppm }\end{array}$ & $\begin{array}{c}\text { Cd } \\
\text { ppm }\end{array}$ & $\begin{array}{c}\text { Bi } \\
\text { ppm }\end{array}$ & $\begin{array}{c}\text { In } \\
\text { ppm }\end{array}$ & $\begin{array}{c}\mathrm{Te} \\
\mathrm{ppm}\end{array}$ & $\begin{array}{r}\text { Ag } \\
\text { ppb }\end{array}$ \\
\hline 11-MPB-520 & background up ice & -4000 & 0 & 6 & 0.5 & 9 & 16 & 15 & 66 & 11 & 0.08 & 1.2 & 0.03 & $<0.02$ & 8 \\
\hline CS-V06B & background up ice & -4000 & NA & 4 & 0.4 & 8 & 22 & 19 & 72 & 16 & 0.13 & 1.1 & 0.03 & $<0.02$ & 10 \\
\hline CS-T07 & background up ice & -3000 & NA & 7 & 0.4 & 4 & 17 & 13 & 57 & 10 & 0.06 & 0.5 & 0.03 & 0.04 & 22 \\
\hline 11-MPB-521 & background up ice & -2250 & 0 & 4 & 0.6 & 8 & 23 & 21 & 87 & 14 & 0.09 & 1.0 & 0.03 & $<0.02$ & 43 \\
\hline CS-V07 & background up ice & -2000 & $\mathrm{NA}$ & 3 & 1.2 & 5 & 12 & 24 & 64 & 26 & 0.10 & 1.8 & 0.04 & $<0.02$ & 39 \\
\hline CS-W07 & background up ice & -2000 & NA & 4 & 1.1 & 4 & 87 & 126 & 130 & 87 & 0.22 & 0.6 & 0.03 & $<0.02$ & 83 \\
\hline CS-T08 & background up ice & -1700 & NA & 5 & 0.5 & 8 & 30 & 38 & 129 & 44 & 0.32 & 0.8 & 0.06 & 0.02 & 105 \\
\hline CS-W07.5 & background up ice & -1500 & NA & 3 & 1.7 & 9 & 81 & 87 & 104 & 92 & 0.13 & 0.6 & 0.08 & 0.05 & 54 \\
\hline 11-MPB-557 & background up ice & -1100 & $\mathrm{NA}$ & 7 & 0.7 & 6 & 22 & 23 & 87 & 29 & 0.17 & 0.9 & 0.05 & $<0.02$ & 313 \\
\hline 11-MPB-552 & proximal up ice & -200 & 0 & 41 & 3.3 & 17 & 367 & 70 & 192 & 178 & 0.73 & 20.0 & 0.30 & 0.30 & 402 \\
\hline 11-MPB-555 & proximal up ice & -200 & 0 & 5 & 0.5 & 6 & 31 & 12 & 54 & 12 & 0.09 & 1.1 & 0.03 & $<0.02$ & 25 \\
\hline 11-MPB-503 & overlying mineralization & 0 & 200 & 397 & 54.8 & 22 & 337 & 98 & 239 & 116 & 0.83 & 15.7 & 0.19 & 0.19 & 384 \\
\hline 11-MPB-505 & overlying mineralization & 0 & 0 & 392 & 39.8 & 15 & 186 & 79 & 150 & 56 & 0.33 & 9.2 & 0.19 & 0.16 & 236 \\
\hline 11-MPB-506 & overlying mineralization & 0 & $\mathrm{NA}$ & 13 & 0.9 & 9 & 42 & 32 & 101 & 35 & 0.25 & 2.3 & 0.06 & $<0.02$ & 73 \\
\hline 11-MPB-507 & overlying mineralization & 0 & 150,000 & 816 & 63.0 & 28 & 310 & 213 & 221 & 114 & 0.82 & 13.5 & 0.21 & 0.51 & 329 \\
\hline 11-MPB-512 & overlying mineralization & 0 & NA & 28 & 2.3 & 9 & 378 & 29 & 90 & 45 & 0.18 & 5.9 & 0.07 & 0.08 & 72 \\
\hline 11-MPB-513 & overlying mineralization & 0 & 0 & 113 & 1.7 & 19 & 456 & 78 & 215 & 80 & 0.80 & 33.3 & 0.16 & 0.24 & 180 \\
\hline 11-MPB-514 & overlying mineralization & 0 & 0 & 28 & 1.9 & 17 & 281 & 76 & 183 & 135 & 0.75 & 25.8 & 0.22 & 0.13 & 234 \\
\hline 11-MPB-515 & overlying mineralization & 0 & $\mathrm{NA}$ & 6 & 0.6 & 5 & 22 & 14 & 64 & 11 & 0.08 & 0.8 & 0.03 & $<0.02$ & 24 \\
\hline 11-MPB-517 & overlying mineralization & 0 & 0 & 18 & 1.3 & 8 & 79 & 45 & 116 & 60 & 0.33 & 6.2 & 0.10 & $<0.02$ & 51 \\
\hline 11-MPB-523 & overlying mineralization & 0 & 15 & 13 & 9.0 & 9 & 51 & 51 & 131 & 74 & 0.36 & 3.1 & 0.06 & $<0.02$ & 259 \\
\hline 11-MPB-541 & overlying mineralization & 0 & NA & 50 & 5.3 & 24 & 268 & 93 & 261 & 92 & 0.92 & 14.3 & 0.28 & 0.19 & 520 \\
\hline 11-MPB-542 & overlying mineralization & 0 & $\mathrm{NA}$ & 5 & 2.9 & 6 & 24 & 11 & 54 & 10 & 0.13 & 0.8 & 0.03 & $<0.02$ & 27 \\
\hline 11-MPB-543 & overlying mineralization & 0 & 0 & 167 & 15.3 & 12 & 122 & 32 & 148 & 36 & 0.62 & 9.4 & 0.11 & 0.13 & 105 \\
\hline 11-MPB-548 & overlying mineralization & 0 & 0 & 133 & 5.2 & 12 & 99 & 29 & 98 & 39 & 0.29 & 7.8 & 0.08 & 0.14 & 144 \\
\hline 11-MPB-549 & overlying mineralization & 0 & NA & 17 & 2.1 & 9 & 70 & 31 & 113 & 26 & 0.33 & 4.4 & 0.08 & 0.08 & 126 \\
\hline 11-MPB-550 & overlying mineralization & 0 & NA & 8 & 0.7 & 10 & 28 & 26 & 94 & 17 & 0.20 & 1.7 & 0.04 & 0.02 & 56 \\
\hline 11-MPB-551 & overlying mineralization & 0 & 200 & 85 & 11.3 & 22 & 578 & 85 & 221 & 92 & 0.69 & 39.1 & 0.27 & 0.54 & 210 \\
\hline 11-MPB-553 & overlying mineralization & 0 & 0 & 65 & 5.4 & 19 & 342 & 67 & 182 & 68 & 0.43 & 24.7 & 0.19 & 0.33 & 182 \\
\hline 11-MPB-554 & overlying mineralization & 0 & NA & 12 & 1.4 & 13 & 119 & 40 & 123 & 62 & 0.41 & 7.7 & 0.12 & 0.10 & 183 \\
\hline 11-MPB-558 & overlying mineralization & 0 & 1 & 39 & 3.6 & 9 & 126 & 22 & 104 & 37 & 0.30 & 6.3 & 0.08 & 0.09 & 114 \\
\hline 11-MPB-559 & overlying mineralization & 0 & NA & 5 & 18.4 & 6 & 20 & 11 & 54 & 13 & 0.10 & 1.0 & 0.02 & 0.03 & 30 \\
\hline 11-MPB-563 & overlying mineralization & 0 & NA & 8 & 1.2 & 5 & 45 & 17 & 91 & 24 & 0.25 & 2.0 & 0.05 & 0.03 & 60 \\
\hline 11-MPB-564 & overlying mineralization & 0 & NA & 18 & 1.2 & 9 & 51 & 24 & 93 & 28 & 0.28 & 3.4 & 0.08 & 0.05 & 61 \\
\hline 11-MPB-565 & overlying mineralization & 0 & NA & 36 & 1.2 & 13 & 108 & 42 & 128 & 28 & 0.48 & 9.5 & 0.10 & 0.06 & 189 \\
\hline 11-MPB-566 & overlying mineralization & 0 & 0 & 9 & 1.2 & 8 & 36 & 19 & 103 & 16 & 0.20 & 2.2 & 0.04 & $<0.02$ & 43 \\
\hline 11-MPB-567 & overlying mineralization & 0 & 50 & 92 & 58.6 & 10 & 107 & 43 & 116 & 58 & 0.37 & 10.2 & 0.08 & 0.18 & 173 \\
\hline 11-MPB-568 & overlying mineralization & 0 & 50 & 325 & 58.3 & 19 & 320 & 108 & 224 & 106 & 0.75 & 14.4 & 0.30 & 0.26 & 309 \\
\hline 11-MPB-569 & overlying mineralization & 0 & 100 & 276 & 26.3 & 15 & 277 & 48 & 153 & 41 & 0.59 & 15.0 & 0.16 & 0.31 & 80 \\
\hline 11-MPB-570 & overlying mineralization & 0 & NA & 30 & 1.7 & 14 & 124 & 45 & 138 & 34 & 0.79 & 10.7 & 0.16 & 0.08 & 116 \\
\hline 11-MPB-571 & overlying mineralization & 0 & NA & 27 & 1.8 & 15 & 111 & 38 & 120 & 33 & 0.41 & 9.7 & 0.13 & 0.07 & 141 \\
\hline 11-MPB-572 & overlying mineralization & 0 & 200 & 126 & 10.4 & 13 & 158 & 61 & 169 & 100 & 0.66 & 15.7 & 0.18 & 0.22 & 417 \\
\hline 11-MPB-573 & overlying mineralization & 0 & 5,000 & 393 & 36.4 & 12 & 184 & 45 & 111 & 28 & 0.24 & 6.7 & 0.10 & 0.15 & 146 \\
\hline 11-MPB-575 & overlying mineralization & 0 & 50 & 41 & 5.2 & 8 & 48 & 26 & 82 & 20 & 0.18 & 3.8 & 0.04 & 0.03 & 52 \\
\hline 11-MPB-576 & overlying mineralization & 0 & 0 & 48 & 0.6 & 3 & 31 & 20 & 82 & 23 & 0.11 & 0.7 & 0.04 & 0.04 & 60 \\
\hline 11-MPB-577 & overlying mineralization & 0 & 1,000 & 290 & 32.6 & 14 & 978 & 24 & 123 & 225 & 0.28 & 54.2 & 0.28 & 0.89 & 252 \\
\hline 11-MPB-578 & overlying mineralization & 0 & 50 & 125 & 16.9 & 13 & 215 & 38 & 139 & 37 & 0.32 & 12.1 & 0.11 & 0.19 & 120 \\
\hline 12-MPB-1026 & overlying mineralization & 0 & 200 & 54 & 4.2 & 6 & 271 & 20 & 53 & 537 & 0.20 & 14.8 & 0.28 & 0.08 & 384 \\
\hline 11-MPB-574 & proximal down ice & 20 & 50 & 42 & 4.5 & 14 & 104 & 36 & 111 & 39 & 0.35 & 6.7 & 0.11 & 0.06 & 181 \\
\hline 11-MPB-502 & proximal down ice & 50 & 0 & 48 & 1.6 & 20 & 400 & 91 & 177 & 257 & 0.56 & 41.7 & 0.41 & 0.39 & 230 \\
\hline 11-MPB-562 & proximal down ice & 100 & 200 & 14 & 1.1 & 12 & 84 & 26 & 105 & 21 & 0.28 & 8.3 & 0.09 & 0.05 & 160 \\
\hline 11-MPB-511 & proximal down ice & 275 & 0 & 65 & 3.7 & 9 & 134 & 26 & 96 & 37 & 0.41 & 7.9 & 0.09 & 0.16 & 161 \\
\hline 11-MPB-518 & proximal down ice & 650 & 0 & 28 & 2.6 & 9 & 191 & 62 & 106 & 266 & 0.18 & 11.6 & 0.14 & 0.13 & 184 \\
\hline CS-W08.5 & proximal down ice & 650 & NA & 50.8 & 3.5 & 21 & 165 & 80 & 80 & 745 & 0.16 & 17.9 & 0.32 & 0.19 & 480 \\
\hline 11-MPB-508 & proximal down ice & 750 & 200 & 69 & 13.0 & 9 & 113 & 46 & 118 & 119 & 0.48 & 4.5 & 0.09 & 0.09 & 347 \\
\hline 11-MPB-509 & proximal down ice & 750 & 200 & 73 & 10.5 & 11 & 132 & 54 & 128 & 148 & 0.37 & 5.7 & 0.09 & 0.03 & 526 \\
\hline 11-MPB-510 & proximal down ice & 900 & 0 & 17 & 0.7 & 8 & 129 & 29 & 91 & 44 & 0.31 & 9.0 & 0.08 & 0.05 & 152 \\
\hline 11-MPB-544 & proximal down ice & 1000 & 0 & 75 & 8.3 & 11 & 179 & 38 & 97 & 79 & 0.24 & 6.1 & 0.10 & 0.18 & 489 \\
\hline CS-VW09 & proximal down ice & 1000 & NA & 10.8 & 1.1 & 7 & 28 & 17 & 65 & 20 & 0.15 & 1.5 & 0.04 & 0.02 & 62 \\
\hline 11-MPB-519 & distal down ice & 1100 & 0 & 41 & 8.0 & 12 & 125 & 50 & 106 & 174 & 0.28 & 12.7 & 0.17 & 0.03 & 303 \\
\hline CS-VW09.5 & distal down ice & 1500 & $\mathrm{NA}$ & 25.5 & 5.4 & 8 & 76 & 33 & 88 & 301 & 0.22 & 4.5 & 0.09 & 0.08 & 164 \\
\hline CS-W09 & distal down ice & 2000 & NA & 2.7 & 0.4 & 3 & 30 & 21 & 85 & 14 & 0.20 & 0.5 & 0.04 & 0.03 & 17 \\
\hline 11-MPB-524 & distal down ice & 2250 & 0 & 15 & 11.2 & 23 & 150 & 474 & 174 & 220 & 0.31 & 2.7 & 0.08 & 0.16 & 557 \\
\hline 11-MPB-546 & distal down ice & 2500 & 0 & 16 & 1.0 & 10 & 84 & 34 & 93 & 71 & 0.26 & 7.6 & 0.07 & 0.04 & 196 \\
\hline 11-MPB-545 & distal down ice & 2800 & 0 & 29 & 2.7 & 11 & 104 & 39 & 102 & 67 & 0.27 & 7.2 & 0.08 & 0.09 & 708 \\
\hline CS-W10A & distal down ice & 3200 & NA & 14.4 & 2.0 & 7 & 93 & 56 & 107 & 102 & 0.39 & 3.9 & 0.09 & 0.12 & 225 \\
\hline 11-MPB-531 & distal down ice & 3500 & 0 & 14 & 1.6 & 9 & 93 & 38 & 110 & 81 & 0.30 & 6.7 & 0.08 & 0.15 & 28 \\
\hline 11-MPB-526 & distal down ice & 3600 & 0 & 13 & 1.6 & 5 & 95 & 28 & 100 & 62 & 0.18 & 2.8 & 0.06 & 0.02 & 336 \\
\hline 11-MPB-530 & distal down ice & 3600 & 0 & 5 & 1.1 & 12 & 43 & 47 & 161 & 36 & 0.38 & 2.1 & 0.14 & 0.04 & 45 \\
\hline 11-MPB-525 & distal down ice & 4300 & 0 & 22 & 1.6 & 7 & 59 & 28 & 73 & 47 & 0.23 & 3.5 & 0.05 & 0.03 & 33 \\
\hline 11-MPB-528 & distal down ice & 5000 & 0 & 9 & 1.3 & 9 & 71 & 43 & 128 & 51 & 0.40 & 4.4 & 0.08 & 0.06 & 30 \\
\hline 11-MPB-529 & distal down ice & 5000 & 0 & 8 & 1.1 & 9 & 68 & 39 & 144 & 60 & 0.45 & 4.4 & 0.07 & 0.05 & 160 \\
\hline
\end{tabular}


Appendix A. Continued.

\begin{tabular}{|c|c|c|c|c|c|c|c|c|c|c|c|c|c|c|c|}
\hline Sample & Interpretation & $\begin{array}{c}\text { distance from } \\
\text { deposit (m) }\end{array}$ & $\begin{array}{l}\text { No. scheelite } \\
\text { grains in pan }\end{array}$ & $\begin{array}{c}\mathrm{W} \\
\mathrm{ppm}\end{array}$ & $\begin{array}{c}\text { Mo } \\
\text { ppm }\end{array}$ & $\begin{array}{c}\text { Sn } \\
\text { ppm }\end{array}$ & $\begin{array}{c}\mathrm{Cu} \\
\mathrm{ppm}\end{array}$ & $\begin{array}{c}\mathrm{Pb} \\
\mathrm{ppm}\end{array}$ & $\begin{array}{c}\mathrm{Zn} \\
\mathrm{ppm}\end{array}$ & $\begin{array}{c}\text { As } \\
\text { ppm }\end{array}$ & $\begin{array}{c}\text { Cd } \\
\mathrm{ppm}\end{array}$ & $\begin{array}{c}\mathrm{Bi} \\
\mathrm{ppm}\end{array}$ & $\begin{array}{c}\text { In } \\
\text { ppm }\end{array}$ & $\begin{array}{c}\mathrm{Te} \\
\mathrm{ppm}\end{array}$ & $\begin{array}{r}\text { Ag } \\
\text { ppb }\end{array}$ \\
\hline ND-A11-2 & distal down ice & 6000 & NA & 3.9 & 0.6 & 5 & 21 & 17 & 57 & 16 & 0.06 & 0.8 & 0.03 & 0.03 & 6 \\
\hline CS-WX11.5-2 & distal down ice & 6200 & NA & 10.9 & 1.1 & 9 & 71 & 37 & 117 & 35 & 0.28 & 4.9 & 0.08 & 0.05 & 30 \\
\hline 11-МРB-527 & distal down ice & 8500 & 0 & 10 & 0.8 & 7 & 33 & 23 & 71 & 30 & 0.19 & 1.7 & 0.03 & $<0.02$ & 26 \\
\hline CS-X12 & distal down ice & 8500 & NA & 3 & 0.8 & 4 & 17 & 18 & 48 & 23 & 0.12 & 0.5 & 0.03 & $<0.02$ & 115 \\
\hline 11-MPB-547 & distal down ice & 8750 & 0 & 8 & 0.8 & 6 & 29 & 18 & 64 & 25 & 0.13 & 1.1 & 0.05 & 0.04 & 16 \\
\hline ND-B12A & distal down ice & 8750 & NA & 8 & 0.8 & 7 & 67 & 44 & 70 & 30 & 0.20 & 2.6 & 0.04 & $<0.02$ & 26 \\
\hline 11-МPB-539 & distal down ice & 10000 & 0 & 13 & 0.9 & 7 & 31 & 19 & 63 & 22 & 0.13 & 1.6 & 0.05 & 0.03 & 14 \\
\hline ND-C13 & distal down ice & 11000 & NA & 5 & 6.7 & 4 & 50 & 26 & 53 & 27 & 0.49 & 0.1 & 0.03 & $<0.02$ & 25 \\
\hline 11-MPB-540 & distal down ice & 13000 & 0 & 4 & 6.0 & 3 & 35 & 19 & 63 & 24 & 0.08 & 0.6 & $<0.02$ & 0.05 & 24 \\
\hline
\end{tabular}

Note: NA = not analyzed. Black horizontal line separating up ice and proximal up ice samples is the threshold between background and metal-rich samples as defined by $\mathrm{W}$ values, the main ore element. Tin and W were determined by borate fusion/ICP-MS, all other elements by aqua regia/ICP-MS. 